Georgia State University

ScholarWorks @ Georgia State University

Computer Information Systems Faculty

Publications

Department of Computer Information Systems

2000

\title{
Quality Management in Systems Development: An Organizational System Perspective
}

T. Ravichandran

Rensselaer Polytechnic Institute, ravit@rpi.edu

Arun Rai

Georgia State University, arunrai@gsu.edu

Follow this and additional works at: https://scholarworks.gsu.edu/cis_facpub

Part of the Management Information Systems Commons

\section{Recommended Citation}

Ravichandran, T., and Rai, A., Quality Management in Systems Development: An Organizational System Perspective, MIS Quarterly, 24(3), September 2000, 381-415. http://misq.org/quality-management-insystems-development-an-organizational-system-perspective.html.

This Article is brought to you for free and open access by the Department of Computer Information Systems at ScholarWorks @ Georgia State University. It has been accepted for inclusion in Computer Information Systems Faculty Publications by an authorized administrator of ScholarWorks @ Georgia State University. For more information, please contact scholarworks@gsu.edu. 


\section{QUALITY MANAGEMENT IN SYSTEMS DEVELOPMENT: AN ORGANIZATIONAL SYSTEM PERSPECTIVE ${ }^{1}$}

\author{
By: T. Ravichandran \\ Lally School of Management and \\ Technology \\ Rensselaer Polytechnic Institute \\ Troy, NY 12180 \\ U.S.A. \\ ravit@rpi.edu \\ Arun Rai \\ Electronic Commerce Institute \\ J. Mack Robinson College of Business \\ Georgia State University \\ Atlanta, GA 30303 \\ U.S.A. \\ arunrai@gsu.edu
}

\begin{abstract}
We identify top management leadership, a sophisticated management infrastructure, process management efficacy, and stakeholder participation as important elements of a quality-oriented organizational system for software development. A model interrelating these constructs and quality performance is proposed. Data collected through a national survey of IS executives in Fortune 1000 companies and government agencies was used to
\end{abstract}

${ }^{1}$ Robert Zmud was the accepting senior editor for this paper. test the model using a Partial Least Squares analysis methodology. Our results suggest that software quality goals are best attained when top management creates a management infrastructure that promotes improvements in process design and encourages stakeholders to evolve the design of the development processes. Our results also suggest that all elements of the organizational system need to be developed in order to attain quality goals and that piecemeal adoption of select quality management practices are unlikely to be effective. Implications of this research for IS theory and practice are discussed.

Keywords: Systems development, information systems management, software quality, TQM theory, software process improvement

ISRL Categories: AF0101, AH05, DD04, EI0206, EI0218, EI0220, FA10

\section{Introduction}

Quality improvement in systems development ranks high among the priorities of Information Systems (IS) managers today. On the one hand, IS units are under pressure to develop application systems that enable organizations to effectively use information technology. On the other hand, these IS units are facing difficulties in delivering systems that meet user needs in a timely and cost 
effective manner. In most organizations, systems development is characterized by recurrent problems, such as poor system quality, long development lead time, user dissatisfaction, and high costs. These problems are compounded by escalating demands for new systems (Cusumano 1991). Further, the need to improve systems development is accentuated because "systems development is not only on the critical path to getting new products or services to market, it is the stumbling block on that path" (Rockart and Hofman 1992, p 21).

Researchers and practitioners have suggested that Total Quality Management (TQM) offers an effective approach to manage quality in the context of systems development (Fox and Flakes 1997; Saracelli and Bandat, 1993; Walrad and Moss 1993; Zultner 1993). Recent surveys indicate that TQM practices are slowly taking root within IS organizations, especially in the context of systems development (Anthes 1997; Fox and Flakes 1997; Williamson 1997). Experiences of organizations such as Corning Inc. (Shrednick et al. 1992) and Dun \& Bradstreet (Kane 1992) indicate that TQM practices lead to improved systems delivery performance. However, the overall impact of TQM initiatives in IS have been mixed; the results range from modest improvements in systems delivery performance to complete abandonment of quality programs. Some scholars attribute these partial or complete failures to unfocused or piecemeal adoption of select practices without understanding the systemic drivers of quality (Zultner 1993), while others claim that TQM in systems development is a paradigm without a solid foundation (Rowe and Neal 1993).

Notwithstanding these opinions, lack of theories in systems development quality limits our understanding of how IS units can develop capabilities to consistently deliver quality systems in a timely and cost effective manner. Our purpose is to make progress toward a theory of quality management in systems development. We take the position that improvements in quality performance occur when an organizational system for quality is put in place and not through piecemeal adoption of TQM practices. The theoretical starting point for this research is Deming's (1986) assertion that quality performance is largely determined by system factors. He argued that a vast majority of variation in work performance is due to common causes, which are system based. At its core, this systems view of quality improvement suggests that quality problems cannot be addressed by patchwork solutions. Instead, management should focus attention on creation and perpetuation of an organizational system geared to achieve superior quality performance.

We draw from the quality management literature to identify and define the key constructs of an organizational system for quality improvement. These constructs are efficacious process management, stakeholder participation, management infrastructure sophistication, and top management leadership for quality. We develop a model that interrelates these constructs and quality performance. The model is based on the view that quality management requires an organizational system perspective. The model is tested using data collected from 123 IS units in Fortune 1000 firms and large government agencies.

The remainder of the paper is organized as follows. The next section provides a critical review of the literature that has examined the information systems quality phenomenon. The subsequent section presents our rationale of conceptualizing software quality management as an organizational system design endeavor. We follow this by defining the major constructs that constitute a quality-oriented organizational system. The following section proposes a model that establishes theoretical relationships between these constructs. Details of the empirical study and the statistical analyses are then presented. The final section interprets the results and discusses the implications of our findings for future research and practice.

\section{Information Systems Quality Management: A Review of the Literature}

Selected quality management concepts have been applied to investigate the information systems quality phenomenon, sometimes without 
explicit reference to and linkage with the total quality management literature. Past research on the IS quality phenomenon has focused on four main areas: (1) software quality measurement and control, (2) the role of development infrastructure, including design methodologies and tools in quality improvement, (3) software process management, and (4) participative design. We summarize significant research in each of these areas and examine the linkages with relevant quality management concepts. We use our critique of the literature to identify shortcomings and gaps in the management of software quality, thereby setting the stage for our own theory development.

Software quality assurance research has emphasized software quality characteristics, software metrics, and quality control techniques and tools (Rai et al. 1998). Key software quality dimensions, including portability, reliability, efficiency, human engineering, and maintainability, have been identified and defined. A variety of metrics for specific software quality characteristics have also been developed and validated. Furthermore, quality control tools and techniques have been developed and their effectiveness in controlling software errors has been examined. While this stream of research continues to evolve, its emphasis has been on the engineering characteristics of the software and limited attention has been paid to assessing and enhancing users' subjective evaluations of the software.

In contrast to the technical focus of software quality assurance research, customer satisfaction is an important objective of TQM initiatives. Customers have specific requirements and products/ services that effectively meet these needs are perceived to be of higher quality (Deming 1986; Juran 1986). Interestingly, a similar perspective is evident in the IS management literature as significant attention has been paid to understanding user requirements and satisfying them. Significant research attention has been directed at identifying the dimensions of user satisfaction and developing reliable and valid instruments for the measurement of this construct (Bailey and Pearson 1983; Galletta and Lederer 1989; Ives et al. 1983). However, the software quality assurance research remains largely uninformed by this stream of IS research. While some studies have used perceived usefulness of the system as a surrogate for systems quality (Franz and Robey 1986) and others have distinguished between technical product quality, product capability, and cost (Hamilton and Chervany 1981), system quality is largely conceptualized as an intrinsic attribute of the software.

Some TQM concepts have been adapted and applied to the software quality assurance domain. Specifically, the application of TQM techniques, such as statistical quality control and quality function deployment, has been explored in the software development context (Stylianou et al. 1997; Zultner 199). Some studies have empirically investigated the impact of these techniques on software quality outcomes (Ahituv and Zelek 1987; Camuoff et al. 1990; Munson and Khoshgoftaar 1992; Okumoto 1985). While these measurement and analytical techniques have been found to be useful in tracking and controlling specific quality problems, their impact on system quality depends on effectively linking individual product and process metrics to broader system quality objectives (Walrad and Moss 1993). Limited research has been undertaken to develop measurement frameworks that link quality objectives to process and product metrics. Furthermore, quality control techniques are unlikely to be effective unless they are an integral part of an organizational system for quality improvement.

A large body of software quality research has conceptualized development as a technical process emphasizing precision and technical accuracy in design and construction. Formal techniques have been proposed to handle the inherent complexity of systems design and facilitate development of technically valid systems. CASE tools that support these techniques are in use today in some IS organizations. Research on the impacts of software process automation suggests that software development tools have a positive effect on code quality, documentation quality, and programmer productivity (Bendure 1991; Rummens and Sucher 1989; Williamson 1990). However, their effect on overall software quality has been marginal because a large proportion of software quality problems originates during requirement definition and system design (Yates 
and Shaller 1990), which involve unstructured tasks that are difficult to automate. Other software process innovations such as reusability are expected to reduce software errors, increase programmer productivity, and reduce development costs (Apte et al. 1990; Banker and Kauffman 1991; Karimi 1990). However, the promise of software reuse has largely been unfulfilled because of the organizational and sociobehavioral hurdles associated with software reuse.

Process improvement is an important TQM concept. Significant research has focused on the design and evolution of software development processes with the intent to enhance their capability and maturity. The Software Engineering Institute (SEI) has developed specific models to evaluate, diagnose, and evolve the capabilities of the development process. SEl's Capability Maturity Model (CMM) defines an evolutionary path from ad hoc, chaotic processes to mature, disciplined processes. Process maturation, as assessed by the predictability of development outcomes in terms of budget, schedules, and quality, is enhanced when feedback is meaningfully generated and utilized to recalibrate and fine tune process design.

The CMM is now popular and has been effective in emphasizing the importance of process improvement. Anecdotal evidence suggests that organizations implementing CMM-based software process improvement have realized gains in development cycle time and programmer productivity (Diaz and Sligo 1997; Haley 1996, Hollenbach et al. 1997). Reports also suggest that organizations face difficulties in adhering to the sequence, as recommended by CMM, in which changes to the development process needs to be implemented (Card 1991; Pfleeger 1996; Saiedian and Kuzara 1995)

The lack of theory informing the conceptualization of the CMM stages raises questions about the rationale for the suggested sequencing to develop process capabilities. Limited attention has been devoted to define process management, identify and define its constitutive dimensions, and develop reliable and valid measurement instruments for each of these dimensions. Furthermore, process improvement is one aspect of TQM that needs to be integrated with other core TQM principles, such as customer focus and viewing the organization with an integrated systems perspective. These essential aspects of TQM are currently missing in the CMM (Paulk et al. 1995). Integrative theory development is required to understand the relationships between process management practices and other elements of the development organization, which enable or constrain effective process management.

Previous IS studies note the importance of managing the psychological and behavioral state of users in the systems development process (Ives et al. 1983). An important finding emerging from this stream of research is that user involvement and user participation should be promoted as they positively impact user satisfaction with IS products and services. Barki and Hartwick (1989) distinguished user involvement from user participation and argued that while the former refers to the subjective psychological state of users, the later refers to users' behaviors and activities during systems development. They went on to suggest that participation is an antecedent to involvement and examined how the two constructs interrelate to impact systems development outcomes (Hartwick and Barki 1994).

Other researchers have adopted a socio-technical systems perspective of information systems design conceptualizing it as an organizational change strategy (Bostrom and Heinen 1977a, 1977b; Mumford 1983; Mumford and Henshall 1979; Mumford and Weir 1979). The system designer is viewed as playing an important role in (re)designing work systems, suggesting that technical system design needs be framed as part of a larger undertaking to (re)design the applicable social system (Bostrom and Heinen 1977a). This stream of research stresses that development processes should incorporate methods to ensure both the technical validity and the organizational validity of developed systems. Toward this end, approaches such as behavior modeling (Mantei and Teorey 1989) and methods to understand deep structures in user's task domain (Leifer et al. 1994), have been suggested. In addition, methodologies such as ETHICS (Mumford 1983) have 
been developed to systematically integrate quality of work life objectives with technical objectives, such as efficiency and control.

Another stream of research has stressed stakeholder participation for realizing emancipatory ideals in systems development. This research stream, largely emanating from Europe, considers participation as important for "social sense-making to create shared understandings and to meet the ethical imperatives of work arrangements in a democratic society" (Hirschheim and Klein 1994; p 84). Projects such as the NJMF, DEMOS (Carlson et al. 1978; Ehn and Sandberg 1983), DUE (DUE 1979; Kyng and Mathiassen 1982), and UTOPIA (Bødker et al. 1987; Ehn and Sandberg 1993) have focused on the institutional aspects of emancipation in systems development. $^{2}$ These projects subscribed to the notion that computer technology contributes to rationalizing work and deskilling workers, and proposed models of negotiation between management and workers and mechanisms to build resources within trade unions so as to increase worker's influence on the design and use of computer systems. The lessons from these projects are referred to as the collective resource approach (Ehn and Kyng 1984; Hirschheim and Klein 1994), which provide a broad set of principles for stakeholder participation in systems development. The socio-technical systems approach emphasizes dependencies and common interests between management and workers and seeks to reconcile conflicts between these groups. In contrast, the collective resource approach embraces the goal of keeping the control of systems development in the hands of workers and trade unions (Bjerknes and Bratteteig 1995; Hirschheim and Klein 1994).

Other methodologies and approaches have emphasized participation as a means to reduce the communication barriers between users and systems analysts, enhance social learning, and emphasize the development of a valid and rich picture of the work setting for which computer systems are being designed. The soft systems methodology adopts an interpretivist approach to

\footnotetext{
${ }^{2} \mathrm{~A}$ more extensive treatment of these projects can be found in Bjerknes and Bratteteig (1995).
}

systems development and stresses systems thinking to understand the purpose of an information system and the context in which it will be used (Checkland and Scholes 1990; Winter et al. 1995). The PIOCO model (Ivari and Koskela 1987) attempts to reconceptualize the systems development life cycle as a learning process and incorporates methods to create awareness of the social situation in which systems development takes place. The MARS project (Lanzara and Mathiassen 1985; Mathiassen and BøghAndersen 1987) also takes a learning perspective, but it focuses directly on work practices and the tools and techniques to record these practices, reflect upon them, and improve their deficiencies (Klein and Hirshheim 1993).

Similar to the participative design literature, TQM proponents have emphasized participation as a means to overcome resistance to change, enhance learning, and improve job satisfaction of workers (Dean and Bowan 1994; Spencer 1994). However, the TQM and participative design literatures depart on how behavioral processes, such as participation, impact performance outcomes. The participative design literature stresses that behavioral processes, such as user participation, directly impact the outcome of systems development. On the other hand, the TQM literature stresses that the design of the organizational system, including the work processes and associated behavioral process, has a far greater influence on task performance than either the work processes or the behavioral processes by themselves (Deming 1986). Thus, stakeholder participation in TQM is accomplished within a carefully defined organizational system and may not necessarily reflect the emancipatory ideals espoused in the participative design literature.

\section{Summary}

While previous research on IS development has examined some important TQM concepts, key gaps in the systems development literature emerge from our literature review. First, a synthesis and integrated analysis of the application of TQM concepts to information systems development has not been undertaken. Consequently, no coherent theory of software quality management 
has emerged. This fails to serve the needs of IS practice, where the consequences of poor quality continue to grow with the increasing importance of and organizational dependence on information systems.

Second, software quality research has focused on the technical and engineering aspects of quality control, while paying limited attention to the organizational dimension of quality management. However, current challenges facing IS development performance improvement are largely organizational and not technical in nature. Paucity of integrative theory-building research within and across important organizational themes, such as leadership, structural arrangements, management processes, and quality outcomes, makes it difficult to envision, design, and implement an organizational system for the management of systems development.

Third, a systemic perspective of quality management is lacking in current IS research. Efforts such as those undertaken by the SEI recognize process improvement as a strategy for the development of capable development processes. Similarly, participative design is recognized as important to formulate the purpose of an information system and develop effective system design for given work settings. However, the linkages between participative approaches and process improvement have not been explored. Furthermore, process management and participative design occur within defined management and organizational contexts. The enabling or constraining roles of contextual factors on these practices have not been systematically examined.

Our objective is to fill the identified gaps in the systems development literature by developing a theory of software quality management that integrates socio-behavioral, organizational, and performance issues from an organizational system perspective. In the next section, we synthesize the TQM and organization design literatures to develop an organizational systems perspective of quality management. We then move on to define the key constructs of a quality-oriented organizational system for IS development.

\section{An Organizational System Perspective of Quality Management}

Total quality management has evolved as an approach to quality that is now characterized as an integrated, systematic organization-wide strategy for improving product and service quality (Dean and Bowen 1994). A fundamental percept of TQM is that organizations should be viewed as systems of interlinked processes. Deming (1986) built a case for treating the organization as a total system and attributed the variations in observed quality performance to the capability of the organizational system. He argued that factors unique to individual workers or specific technology account for a minimal proportion of the variation in quality performance and that most performance variations are due to system factors. Underlying the systems view of quality improvement is the notion that employees work in an organizational system and that the individual and collective behavior of employees can be manipulated through changes to the elements of the organizational system. Furthermore, patchwork solutions targeted on an ad-hoc basis at work processes may not be effective. Instead, managerial attention should be focused on designing a total system capable of achieving the desired level of quality performance. Such a system is much broader than work processes; it includes management processes and structural arrangements created to steer the organization toward its quality goals. Deming (1986, p.366) noted

$$
\begin{aligned}
& \text { few people in industry know what } \\
& \text { constitutes a system. Many people think } \\
& \text { machinery and data processing when I } \\
& \text { mention systems. Few of them know that } \\
& \text { recruitment, training, supervision and } \\
& \text { aids to production workers are part of the } \\
& \text { system. }
\end{aligned}
$$

Deming's conceptualization of an organization as a behavioral system is consistent with the macroperspective of organization design founded on Barnard's (1938) notion of organizations as purposeful systems of coordinated action. This perspective takes the organization or its major sub-units as the primary unit of analysis. Leadership, structural arrangements, and organizational 
processes are considered the major building blocks of an organization that could be manipulated to achieve desired behavior and outcomes (Melcher 1976; Robey 1986). A generally accepted relationship between these elements is that leadership drives the creation of structure and processes necessary to achieve organizational goals (Melcher 1976). Moreover, processes are controlled partly through the design of structure (Melcher 1976; Robey 1986). Traditionally, structure has been defined in terms of organizational hierarchies, job descriptions, and control and coordination mechanisms. Robey cautions researchers against being overly mechanical in defining structure and argues that structure should be viewed more broadly as actions taken to perpetuate patterns of behavior among people. This broad definition of structure includes organizational policies, procedures, and reward schemes that influence the behavior of organizational members.

From this theoretical perspective, TQM in systems development can be viewed as an organizational design endeavor involving changes to leadership, structural arrangements, and core design and production processes. Senior IS management provides the leadership for quality improvement and drives the creation of structural arrangements that shape the IS quality environment and perpetuate quality-oriented behavior among IS personnel. In addition, core design and production processes and associated work practices have to be designed to channel the forces created by the quality environment toward learning and ongoing process improvement. Systematic process level changes are expected to result in mature organizational processes and continuous improvement of product quality and process efficiency.

\section{Key Constructs of a Quality Oriented Organizational System}

Table 1 presents the key constructs of an organizational system for quality improvement identified based on an extensive review of the quality management literature. The constructs include top management leadership for quality, management infrastructure sophistication, pro- cess management efficacy, stakeholder participation, and quality performance. Top management leadership for quality pertains to the extent to which senior IS management is committed to quality improvement and envisions quality initiatives for their systems development organization. Management infrastructure represents a structural property of the IS organization that creates a quality-oriented organizational environment for core processes and work practices. The quality management literature emphasizes that management of the core operational processes and associated behavioral processes are essential elements of a quality-oriented organizational system (Dean and Bowen 1994; Garvin 1998). Process management efficacy is defined here as the degree to which core design and development processes are defined, controlled, and improved in a systematic manner. A key behavioral process that has been emphasized in both the quality management and systems development literature is the participation of stakeholders. Stakeholder participation represents the degree to which work practices are established so that a constituent group contributes its knowledge base and complements the knowledge resources of other constituent groups involved in systems development. Quality performance is defined as the degree to which objectives of product quality and process efficiency are met by the systems development organization.

Recent studies have synthesized existing TQM frameworks and identified important properties of quality management in organizations (Ahire et al. 1996; Flynn et al. 1994; Saraph et al. 1989). Collectively, the factors identified in these three studies represent a comprehensive set of quality management practices that have been emphasized by researchers, practitioners, and quality consultants. As part of our theory-building process, we ascertained the applicability of these properties to the domain of systems development. Furthermore, we examined how these properties relate to the higher level constructs that we have identified as defining a quality-oriented organizational system. We logically examined how the identified properties map into the constructs of top management leadership, management infrastructure sophistication, process management efficacy, stakeholder participation, and quality performance. 


\begin{tabular}{|c|c|}
\hline $\begin{array}{c}\text { Macro Organization Design } \\
\text { Variables }\end{array}$ & $\begin{array}{c}\text { Elements of a Quality Oriented } \\
\text { Organizational System }\end{array}$ \\
\hline Leadership & - Top Management Leadership for Quality \\
\hline Structure & - Management Infrastructure \\
\hline Process & $\begin{array}{ll}\text { - } & \text { Process Management } \\
\text { - Stakeholder Participation }\end{array}$ \\
\hline Outcome & - Quality Performance \\
\hline
\end{tabular}

Table 2 presents a summary of the constructs and their underlying constitutive properties. A total of 13 properties were identified which mapped into the five higher level constructs. The table also compares the quality management properties defined by Saraph et al. (1989), Flynn et al. (1994) and Ahire et al. (1996). We note a strong degree of consensus among these researchers on the important properties associated with a qualityoriented organizational system. We now proceed to define and discuss each of our constructs and their constitutive properties and then proceed to develop the interrelationships among these constructs.

\section{Top Management Leadership for Quality}

Deming (1986) asserts that without senior management's leadership and visible signaling of their commitment to quality improvement, an organization will not be able to change its practices that lead to poor quality. In fact, top management leadership is one factor that has been consistently emphasized by all quality management frameworks (Crosby 1979; Deming 1986; Juran 1986; Schoenberger 1984; Shingo 1986). Empirical studies also indicate that top management leadership can encourage practices and behaviors that lead to superior quality performance (Anderson et al. 1995; Flynn et al. 1995; Saraph et al. 1989). Theoretical support for this finding can be found in transformational leadership theories (Bass 1985; Tichy and Devanna 1986), which suggests that senior management can encourage the pursuit of change by formulating and communicating a vision for the future and reinforcing values that support the vision. Several processes are likely to be operating when top management stimulates the transformation of values (Waldman 1994). Senior management may demonstrate confidence and moral conviction in their values (House 1977), espouse an appealing vision that generates enthusiasm for certain valueladen ideological goals (Conger and Kanungo 1987; Tichy and Devanna 1986), and serve as role models for the value system (Waldman 1994). This requires their personal involvement in activities such as quality planning and performance review, ownership of responsibility for quality performance, and providing support to quality initiatives (Baldrige Award 1992; Deming 1986). Thus, top management leadership is the first antecedent of quality performance.

\section{Management Infrastructure Sophistication}

Management's quality vision has to be translated into actions if it is to result in quality improvements. To be effective, the vision must be embodied in the policies and structures of the organization (Fenwick 1991; Scholtes and Hacquebord 1988; Selznick 1957; Shores 1992). These policies and structures are required to create the forces that steer the organization toward desired goals (Adler 1989).

The skill base of an organization is an important determinant of benefits realized from change initiatives, such as quality management. Training 


\section{Table 2. Summary of Quality Management and Quality Performance Factors}

\begin{tabular}{|c|c|c|c|c|}
\hline $\begin{array}{l}\text { Theoretical } \\
\text { Constructs }^{a}\end{array}$ & $\begin{array}{l}\text { Saraph et al. } \\
\text { (1989) }\end{array}$ & $\begin{array}{l}\text { Flynn et al. } \\
\text { (1994) }\end{array}$ & Ahire et al. (1996) & Our Study \\
\hline $\begin{array}{l}\text { Top } \\
\text { Management } \\
\text { Leadership }\end{array}$ & \multirow{2}{*}{$\begin{array}{l}\text { Top manage- } \\
\text { ment leadership } \\
\text { and quality policy }\end{array}$} & $\begin{array}{l}\text { Top manage- } \\
\text { ment support }\end{array}$ & $\begin{array}{l}\text { Top management } \\
\text { commitment }\end{array}$ & $\begin{array}{l}\text { IS management } \\
\text { support for quality }\end{array}$ \\
\hline \multirow{3}{*}{$\begin{array}{l}\text { Management } \\
\text { Infrastructure } \\
\text { Sophistication }\end{array}$} & & $\begin{array}{l}\text { Quality policy not } \\
\text { explicitly } \\
\text { considered }\end{array}$ & Not considered & $\begin{array}{l}\text { Quality policy and } \\
\text { goals }\end{array}$ \\
\hline & Training & $\begin{array}{l}\text { Included under } \\
\text { work force } \\
\text { management }\end{array}$ & Employee training & $\begin{array}{l}\text { Commitment to } \\
\text { skill development }\end{array}$ \\
\hline & $\begin{array}{l}\text { Nature of reward } \\
\text { schemes } \\
\text { included under } \\
\text { employee } \\
\text { relations }\end{array}$ & $\begin{array}{l}\text { Considered } \\
\text { under top } \\
\text { management } \\
\text { support }\end{array}$ & $\begin{array}{l}\text { Considered under } \\
\text { employee involve- } \\
\text { ment but dropped } \\
\text { from the validated } \\
\text { scale }\end{array}$ & $\begin{array}{l}\text { Quality orientation } \\
\text { of reward schemes }\end{array}$ \\
\hline \multirow{5}{*}{$\begin{array}{l}\text { Process } \\
\text { Management } \\
\text { Efficacy }\end{array}$} & \multirow{2}{*}{$\begin{array}{l}\text { Product/service } \\
\text { design }\end{array}$} & \multirow[b]{2}{*}{ Product design } & \multirow{2}{*}{$\begin{array}{l}\text { Design quality } \\
\text { management }\end{array}$} & $\begin{array}{l}\text { Formalization of } \\
\text { analysis and } \\
\text { design }\end{array}$ \\
\hline & & & & $\begin{array}{l}\text { Formalization of } \\
\text { reusability in } \\
\text { systems } \\
\text { development }\end{array}$ \\
\hline & $\begin{array}{l}\text { Process } \\
\text { management }\end{array}$ & $\begin{array}{l}\text { Process } \\
\text { management }\end{array}$ & SPC usage & Process control \\
\hline & \multirow{2}{*}{$\begin{array}{l}\text { Quality data and } \\
\text { reporting }\end{array}$} & \multirow{2}{*}{$\begin{array}{l}\text { Quality } \\
\text { information }\end{array}$} & $\begin{array}{l}\text { Internal quality } \\
\text { information usage }\end{array}$ & \multirow{2}{*}{$\begin{array}{l}\text { Fact based } \\
\text { management }\end{array}$} \\
\hline & & & Benchmarking & \\
\hline \multirow{4}{*}{$\begin{array}{l}\text { Stakeholder } \\
\text { Participation }\end{array}$} & \multirow{2}{*}{$\begin{array}{l}\text { Employee } \\
\text { relations }\end{array}$} & \multirow{2}{*}{$\begin{array}{l}\text { Work force } \\
\text { management }\end{array}$} & $\begin{array}{l}\text { Employee } \\
\text { empowerment }\end{array}$ & \multirow{2}{*}{$\begin{array}{l}\text { Empowerment of } \\
\text { programmer/ } \\
\text { analyst }\end{array}$} \\
\hline & & & $\begin{array}{l}\text { Employee } \\
\text { involvement }\end{array}$ & \\
\hline & $\begin{array}{l}\text { Supplier quality } \\
\text { management }\end{array}$ & $\begin{array}{l}\text { Supplier } \\
\text { involvement }\end{array}$ & $\begin{array}{l}\text { Supplier } \\
\text { performance }\end{array}$ & $\begin{array}{l}\text { Vendor/consultant } \\
\text { participation }\end{array}$ \\
\hline & $\begin{array}{l}\text { Customer } \\
\text { involvement not } \\
\text { explicitly } \\
\text { considered } \\
\end{array}$ & $\begin{array}{l}\text { Customer } \\
\text { involvement }\end{array}$ & Customer focus & User participation \\
\hline \multirow[b]{2}{*}{$\begin{array}{l}\text { Quality } \\
\text { Performance }\end{array}$} & $\begin{array}{l}\text { Not explicitly } \\
\text { considered }\end{array}$ & $\begin{array}{l}\text { Product quality in } \\
\text { terms of scrap } \\
\text { rate }\end{array}$ & Product quality & Product quality \\
\hline & $\begin{array}{l}\text { Process quality } \\
\text { not explicitly } \\
\text { considered as a } \\
\text { performance } \\
\text { measure }\end{array}$ & $\begin{array}{l}\text { Process quality } \\
\text { not explicitly } \\
\text { considered as a } \\
\text { performance } \\
\text { measure }\end{array}$ & $\begin{array}{l}\text { Process quality not } \\
\text { explicitly considered } \\
\text { as a performance } \\
\text { measure }\end{array}$ & Process efficiency \\
\hline
\end{tabular}

\footnotetext{
${ }^{\mathrm{a}}$ The conceptualization of the higher level constructs identified here is part of the theory building effort of this project.
} 
is commonly used in organizations to facilitate members' understanding of change initiatives and influence their attitudes toward change. Furthermore, skill and knowledge of employees have to be constantly upgraded in order to sustain continuous process improvement (Deming 1986). Hence, organizational commitment to skill enhancement and the processes used to achieve this are important aspects of the management infrastructure.

Whether the skills are effectively utilized depends on organizational policies that determine the role people are called upon to play. Explicit policies are required to stress the importance of quality over other objectives and focus the attention of all organizational members on attainment of quality goals (Baldrige Award 1992; Juran 1986). Organizations with successful quality programs use techniques such as policy deployment to define employee roles.

Organizations are realizing the need to refocus reward schemes to emphasize quality objectives. According to a 1991 Conference Board survey, $85 \%$ of organizations implementing TQM have developed programs to reward individuals and teams for quality achievements. In addition, many of these organizations integrate employee performance appraisals with quality performance. A 1991 KPMG Peat Marwick survey found that $60 \%$ of organizations that have five or more years of TQM experience explicitly rewarded the achievement of quality goals. Blackburn and Rosen (1993) point out that Baldrige award winners reoriented their reward schemes to emphasize continuous improvement and teamwork. Within the IS context, changes to reward structures have been found necessary to promote quality oriented behavior among systems development teams. For example, Shrednick et al. (1992) found that incentives provided for spending within budget, customer satisfaction, process improvement, and cost reduction resulted in significant improvements in the service quality of IS teams at Corning Inc. Kane (1992) found that Dun \& Bradstreet Software incorporated performance contingent rewards to drive improvements of their software development process.
Organizational commitment to skill development, quality policy and goals, and quality-oriented reward schemes are critical aspects of an organizational system for quality. Together these factors represent what we call the management infrastructure for quality. IS units that have adopted these practices have a sophisticated management infrastructure and hence are better prepared to redesign, formalize, manage, and continuously improve core design and development processes. Conversely, IS units that have not adopted these practices have a less sophisticated management infrastructure and hence may lack the capability to effectively implement process level improvements that lead to quality outcomes. Thus, management infrastructure sophistication is the second antecedent of quality performance.

\section{Process Management Efficacy}

Quality processes are a necessary prerequisite for delivering quality products/services and satisfying customer needs (Deming 1986). Organizations are systems of interlinked processes and the effectiveness of organizational processes essentially determines the quality of products and services. Efforts should be targeted at putting in place well-defined, state-of-the-art processes and then continuously improving them by eliminating waste and sources of customer dissatisfaction. This involves extensive data collection, analysis, and feedback systems that help isolate problems and direct employee attention at resolving identified problems (Sitkin et al. 1994). Process improvements eventually result in mature organizational processes that are optimized and in control.

Process improvement originated in statistical process control theories and has evolved to include practices aimed at total waste elimination through continuous improvement. These practices are oriented toward extraction, synthesis, and codification of information presented by process variations and systematically embedding the resultant knowledge through changes in process parameters. Accordingly, fact-based management and process control are important properties of a systems development process focused on learning and improvement. Fact-based manage- 
ment pertains to the extent to which quality data is systematically collected and used in formulating quality improvement actions. Process control pertains to the extent to which explicit performance standards have been established and are used to control systems development outcomes.

In addition to techniques directed at improving and controlling processes, approaches aimed at improving product and service designs are an integral part of process management. Poor quality is largely attributed to design problems (Cole 1981), which can be avoided if (1) explicit attention is paid to potential quality problems during design (Garvin 1987; Taguchi and Clausing 1990), (2) customer requirements are understood better (Shingo 1986), and (3) design is modularized to facilitate reuse of proven design primitives (Shingo 1986). Hence, practices that reduce or eliminate quality problems due to design weaknesses are critical aspects of a systems development process. Formalization of analysis and design methods to focus attention on customer needs and develop complete and accurate requirements is an important property of a quality-oriented systems development process. Formalization of analysis and design methods pertains to the extent to which adherence to standard systems design techniques and methods is integral to the systems development process.

An important theme underlying the design of TQM processes is waste elimination and error prevention, as opposed to error detection. Design and code modules that have been effectively developed and tested for other application systems can often be deployed elsewhere in similar application development contexts. Such a strategy is oriented to reduce duplication, waste, and introduction of unnecessary errors in the development process. Thus, formalization of reusability in systems development is recognized as an important property of an efficacious systems development process. Formalization of reusability pertains to the extent to which reuse is encouraged and enforced as part of ongoing systems development tasks.

\section{Stakeholder Participation}

A central theme of quality management is that technical and human aspects of a process must be managed in concert. Complementing the design of efficacious development processes, work design practices that foster participation of key stakeholders and empowerment of employees need to be established. In fact, efficaciously managed processes bring together the principles of scientific management (Taylor 1911) and the human relations approach to work design (Drucker 1990; Grant et al. 1994). The continuous process improvement cycle of plan-do-check-act is oriented to remove variations caused by unscientific task/process design. However, unlike Taylor's scientific management, TQM principles do not encourage separation of task/process design and execution (Anderson et al. 1994). Empowering workers to design tasks, modify processes, and participate in decisions related to their tasks makes work meaningful to them and creates conditions where employees will be intrinsically motivated to engage in goal oriented behavior (Conger and Kanungo 1987).

Participation of users, vendors, and developers in the core design and development processes promotes mutual understanding of issues and constraints to be addressed to improve quality. User participation promotes rich information exchange between users and the IS organization and increases the chances that aspects valued by the users are factored into systems design. Often, the knowledge resources needed to effectively meet stringent user demands are dispersed within and outside the organization. Vendors possess deep knowledge about emergent technologies and their deployment in different organizations and industries. Vendor participation allows the IS unit to tap into knowledge resources dispersed outside the organization and utilize these resources to improve quality. Participation by programmers/analysts in the determination of schedules, resource allocation, and project plans is likely to result in a deeper understanding of the specifics of a project, and its implications for the development process, that may otherwise be absent in development process conceptualizations.

In summary, process management efficacy and stakeholder participation are important antecedents of quality performance. Formalization of design methods, formalization of reusability, factbased management, and process control are 
integral to efficacious management of the development process. Participation of key stakeholders, such as customers, vendors, and programmers/ analysts, is essential for these practices to evolve on an ongoing basis.

\section{Quality Performance}

\section{Product Quality}

Product quality pertains to the value of the product in terms of its attributes. The most pervasive definition of quality currently used is the extent to which a product or service meets or exceeds a customer's expectations. This definition of quality is implicit in the TQM principles and has come to be recognized as a valid, externally focused measure of quality. It captures what is important to the customers and includes subjective factors that are critical to customers but difficult to quantify into assessments of quality.

\section{Process Efficiency}

Process measures of quality are equally important from a customer's perspective, as they bear relation to the cost of goods and services and their efficient delivery. Product quality cannot be thought of apart from product cost (Feigenbaum 1991). From a customer's perspective, availability, price, and convenience are other factors that complement product quality in the sense that they focus on the process of product/service delivery and reflect the efficiencies of these processes. Thus, process efficiency is an important dimension of quality performance.

\section{An Organizational System Model for Software Quality Management}

We now present our conceptualization of how key organizational design constructs interrelate to form a quality-oriented organizational system for software development. The model is rooted in the macro organizational design perspective in that it includes top management leadership, management infrastructure sophistication, process management efficacy, and stakeholder participation as the constitutive elements of the organizational system. Furthermore, the model embodies the essentially sequential relationship between structure, processes, and outcome that is implicit in the macro design perspective of organizations.

Table 3 depicts the relationships between the constructs in the model. The full model adopts a directed-change perspective of quality management and depicts that top management commitment has a direct effect on management infrastructure sophistication, process management efficacy, and stakeholder participation. Management infrastructure sophistication, in turn, directly impacts process management and stakeholder participation. Both process management efficacy and stakeholder participation directly impact quality outcomes. Organizations adopting a directed-change perspective seek to establish tight control over work processes, improve process efficiency, and reduce variability in tasks and process outputs. Consequently, these organizations might favor a direct involvement of the senior management in designing and implementing process level changes and in promoting stakeholder participation.

There is some empirical support for this model in the operations management literature. Flynn et al. (1995) present a relatively comprehensive effort to define an organizational system for quality. They categorized quality management practices into top management leadership, infrastructure practices, and core practices and posited causal relationships between them. Practices such as statistical control and feedback, work flow management, and design process management constituted core practices, while practices oriented toward changing worker attitudes, establishing relationships with customers and vendors, and developing a quality-focused organizational climate constituted infrastructure practices (Flynn et al. 1995). They found core practices directly related to quality performance, while infrastructure practices created the environment that supports the effective use of core practices. They also found top management leadership to have a direct effect on the systemic elements of TQM, which include both core and infrastructure practices. 
The nested model underscores an empoweredchange perspective of quality management in that work processes are conceptualized and driven by process stakeholders. Management provides unequivocal support for the change program and orients the management infrastructure to be supportive of the general nature of the change being planned. Thus, their responsibility shifts to developing policies, stating goals, and communicating without contradiction that they are supportive of the change program. Contradictions between orientation of the change program and orientation of the management infrastructure, such as nature of training and reward systems, need to be eliminated. It is through the design of the management infrastructure that top management establishes the context to suffocate or promote improvements to the design of the process and participation of stakeholders.

There is empirical evidence in the operations management literature providing support for the empowered change perspective of TQM implementation. Anderson et al. (1994) operationalized seven concepts underlying Deming's method of quality management: visionary leadership, internal and external cooperation, learning, process management, continuous improvement, employee fulfillment, and customer satisfaction. They developed and empirically tested a model of quality management with hypothesized causal relationships among these seven constructs (Anderson et al. 1995). According to them, commitment to quality exemplified by visionary leadership leads to the creation of an organizational environment characterized by cooperation and learning which, in turn, facilitates process improvement. Effective process management leads to outcomes such as continuous improvement, employee fulfillment, and customer satisfaction. They found that process management has a direct effect on quality outcomes, while practices that foster learning and cooperation indirectly impact quality outcomes by facilitating process management. Further, top management leadership did not have a direct effect on quality outcomes or process management. Instead, it indirectly affected process management by impacting the development of a learning and cooperative organizational environment for process stakeholders.

\section{Empirical Study}

\section{Survey}

A national survey was conducted to collect data for the study. The population of interest is IS units that develop application systems in-house. We limited our sampling frame to IS organizations in Fortune 1000 companies and large government agencies. We followed a systematic approach in constructing the mailing list for the survey. First, the Fortune 1000 organizations were identified through a search of the Compustat corporate database. Organizations such as holding companies, conglomerates, and trusts were dropped from the mailing list. This yielded a set of 700 organizations. Next, the mailing addresses for these organizations were obtained from the Directory of Top Computer Executives (1994). Organizations not listed in the directory were dropped, resulting in a set of 605 Fortune 1000 companies. Finally, 105 federal and state government agencies were randomly chosen from the same directory to construct the total sample for the study.

Senior IS executives were chosen as the respondents as they are likely to be most informed about quality initiatives in IS units. The names of senior IS executives in the sampled organizations were identified from the Directory of Top Computer Executives. Where multiple names were found, the most senior person was chosen as the respondent. A total of 710 questionnaires were mailed. A total of four mailings, each spaced apart by three weeks, were undertaken. A total of 123 usable responses were received, resulting in a response rate of $17.32 \%$ (Table 3 ).

The response rate is modest but close to the minimum recommended level of $20 \%$ for organizational surveys (Grover 1997; Yu and Cooper 1983) and similar to those obtained in many IS surveys (Pinsonneault and Kraemer 1993). Nevertheless, it is recommended that all efforts be made to maximize response rates and reduce the chances of sampling error (Yu and Cooper 1983).

We took several steps to mitigate the chances of sampling error. First, we provided incentives (such as a summary of the survey results and a pack of 


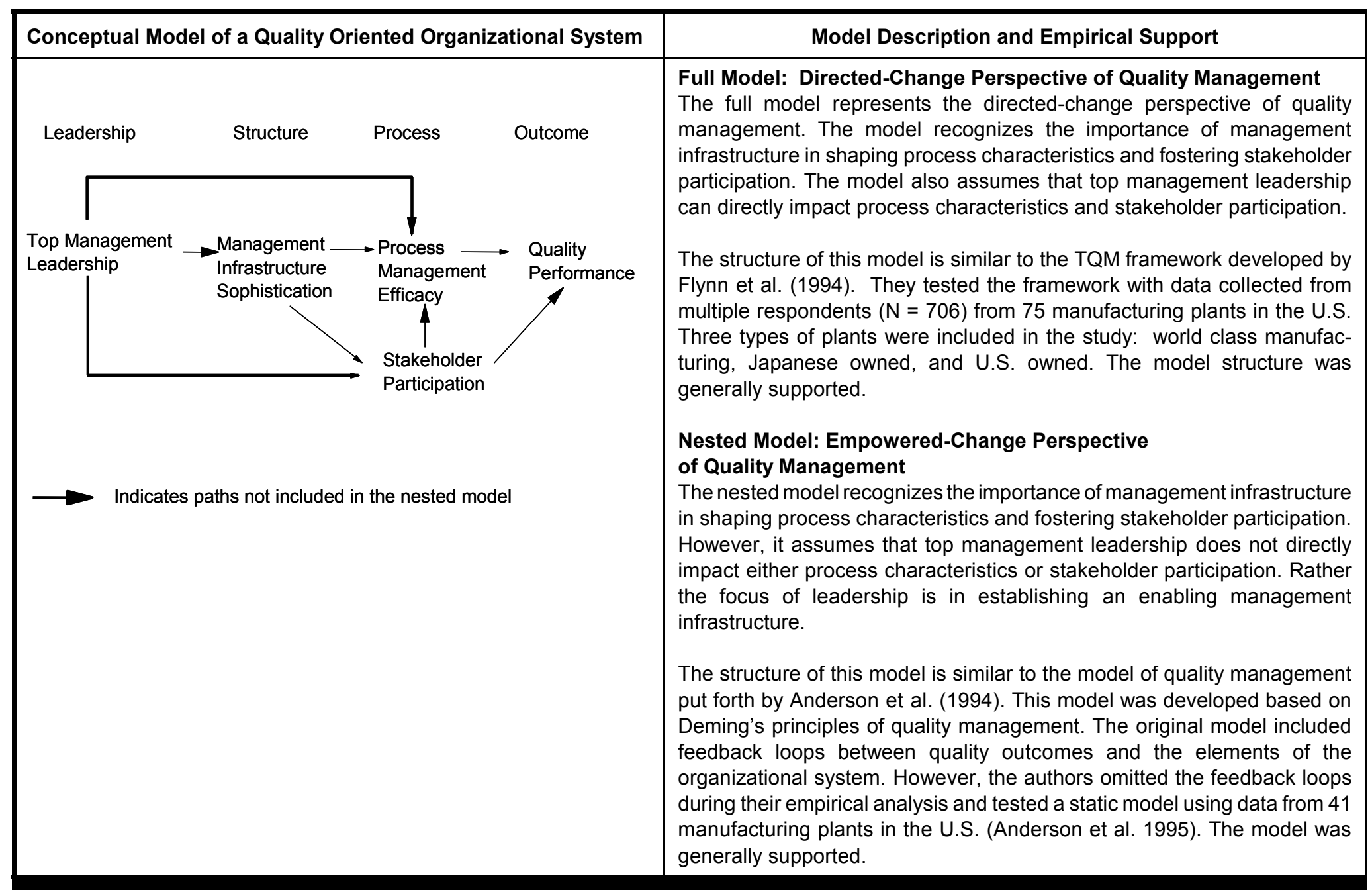

Figure 1. Conceptual Model of a Quality Oriented Organizational System for Information Systems Development 


\begin{tabular}{|c|c|c|c|c|}
\hline No. & Industry & $\begin{array}{c}\text { Effective No. of } \\
\text { Questionnaires Mailed }\end{array}$ & $\begin{array}{l}\text { No. of Responses } \\
\text { Received }\end{array}$ & $\begin{array}{c}\text { Response Rate } \\
\%\end{array}$ \\
\hline 1 & Manufacturing & 338 & 64 & 18.93 \\
\hline 2 & Insurance & 34 & 6 & 17.65 \\
\hline 3 & Utilities & 34 & 6 & 17.65 \\
\hline 4 & Transportation & 29 & 6 & 13.79 \\
\hline 5 & Retail & 32 & 5 & 15.63 \\
\hline 6 & Banks & 61 & 8 & 13.11 \\
\hline 7 & $\begin{array}{l}\text { Financial } \\
\text { Services }\end{array}$ & 25 & 5 & 20.00 \\
\hline 8 & Div. Services & 52 & 5 & 9.62 \\
\hline 9 & Government & 105 & 18 & 17.14 \\
\hline & Total & 710 & 123 & 17.32 \\
\hline
\end{tabular}

coffee) to respondents and conducted multiple mailings to improve our response rate. Second, we polled nonrespondents to assess the reasons for nonresponse and check if factors specific to our study accounted for the modest response rate. Finally, we systematically checked for nonresponse bias by comparing respondents with nonrespondents.

A telephone poll of 60 randomly chosen nonrespondents was conducted. A standard protocol was developed to structure the telephone conversations so as to ensure that the questions posed to the participants were similar. The questions focused on the reasons for nonresponse, the relevance of our survey to the organization, and whether the organization had adopted TQM in its IS units. The major reasons for nonresponse indicated were (1) the large number of surveys received by them $(53.3 \%),(2)$ company policy not to respond to surveys $(13.1 \%)$, (3) length of the questionnaire $(16.6 \%)$, (4) lack of interest in the survey theme $(8.3 \%)$, and (5) lack of time due to other commitments (such as organizational restructuring) (8.3\%). These results suggest that the significant reasons for nonresponse are not specific to this study and represent a more general trend. However, it is likely that the length of our survey instrument could have deterred a small proportion (16\%) of the surveyed population from participating in our study. Furthermore, 38\% of the 60 nonrespondents polled indicated that they had not adopted TQM practices in their IS units. More importantly, $69.8 \%$ of survey respondents reported that they had adopted TQM in IS development. While we polled only 60 nonrespondents, it appears that nonadopters of TQM may have been more likely not to respond to our questionnaire, raising some cautionary implications for the external validity of our findings.

Proportionate classification of respondents and nonrespondents were compared on key organizational characteristics such as industry (SIC codes), organization size (measured in natural logarithm of number of employees), and annual revenue. The chi-square analysis provided evidence of the absence of response bias. Table 3 indicates that the response rate did not vary much across industry segments providing further evidence of the absence of response bias.

In addition to comparing respondents and nonrespondents, it is recommended that early and 
late respondents be compared. The respondents were split into three equal groups based on their response date. One-way ANOVA was used to test for differences between the first (early respondents) and the third (late respondents) group on a variety of demographic variables such as industry, organization size, ISD size, and time since adoption of quality management practices. No systematic response bias was found, suggesting that the respondents can be pooled with no loss in generalizability.

Our sample represents a broad cross-section in terms of industry, organization size, and IS department size. Of the respondents, $52.03 \%$ were manufacturing firms, $33.33 \%$ were service organizations, and $14.64 \%$ were government agencies. Of the firms responding, $21.7 \%$ had 500 or fewer employees, $32.5 \%$ had between 500 and 5,000 employees, $40 \%$ had more than 5,000 employees (median 3,900 employees). Of the firms responding, $25 \%$ had 50 or fewer employees in their information systems units, $15 \%$ had between 50 and 100 employees, $20 \%$ had between 100 and 200 employees, and $40 \%$ had more than 200 employees (median 137 employees). The respondents were senior IS executives (Director of MIS, $62.4 \%$, CIO, 21.3\%, Vice President, MIS, 12.4\%) and $82 \%$ of them were within two levels from the CEO in the organizational hierarchy.

\section{Measures}

The constructs that need to be operationalized are top management leadership, management infrastructure sophistication, process management efficacy, stakeholder participation, and quality performance. Earlier, we discussed the 13 constitutive properties associated with these constructs. The scales for these 13 factors are summarized in Appendix A. The scales were refined based on a pilot study conducted with two IS executives, two software quality consultants, and four IS researchers working in the area of systems development. Using the data collected from the mail survey, unidimensionality, reliability, convergent validity, and discriminant validity of the scales were assessed through confirmatory factor analysis. Furthermore, the criterion-related validity of the quality management scales were assessed. Appendix B summarizes the results of scale validation. The results indicate that all of the scales are unidimensional and meet acceptable levels of reliability and validity.

Based on the constitutive definition of the quality management constructs presented earlier, we mapped each of the 13 factors to their respective higher level constructs, namely top management leadership, management infrastructure sophistication, process management efficacy, stakeholder participation, and quality performance. Factor scores computed by averaging the item scores for each factor were used as indicators of the constructs in the research model.

\section{Statistical Analysis and Results}

\section{Partial Least Squares}

We used the partial least square (PLS) method of structural modeling to test the research models. ${ }^{3}$ In PLS, latent constructs can be modeled as either formative or reflective constructs. ${ }^{4}$ Indicators of reflective constructs are viewed as affected by the same underlying construct and are parallel measures that covary to the extent that they measure the underlying construct. Formative indicators are measured variables that are assumed to cause a latent variable. They combine to approximate the underlying construct and are weighted according to the relative importance in forming the construct. These indicators are not necessarily correlated. Rather, each indicator may occur independently of the others (Chin and Gopal 1995). In our models, management infrastructure sophistication, process management efficacy, stakeholder participation, and quality performance are formative constructs, each with three, four, three, and two indicators respectively. Top management leadership is a reflective construct with one indicator.

\footnotetext{
${ }^{3}$ The PLS analyses including the significance tests for the path coefficients were performed using PLS-GRAPH.

${ }^{4}$ We thank the associate editor for pointing out the distinctions between formative and reflective constructs. For a detailed treatment of this topic, the readers are referred to Cohen et al. (1990) and Chin and Gopal (1995).
} 


\begin{tabular}{|l|l|c|c|}
\hline \multicolumn{1}{|c|}{$\begin{array}{c}\text { Table 4. Weights and Loadings for the Full Model } \\
\text { (Reflective/Formative) }\end{array}$} & \multicolumn{1}{|c|}{ Indicators } & Loadings & Weights \\
\hline $\begin{array}{l}\text { Top Management Leadership } \\
\text { (reflective) }\end{array}$ & IS Management Support for Quality & 1.00 & 1.00 \\
\hline \multirow{4}{*}{$\begin{array}{l}\text { Management Infrastructure } \\
\text { Sophistication (formative) }\end{array}$} & Quality Oriented Policy & $0.90^{*}$ & $0.66^{*}$ \\
\cline { 2 - 4 } & Quality Orientation of Rewards & $0.72^{*}$ & $0.37^{*}$ \\
\cline { 2 - 4 } & Commitment to Skill Development & $0.72^{*}$ & $0.19^{+}$ \\
\hline \multirow{4}{*}{$\begin{array}{l}\text { Process Management Efficacy } \\
\text { (formative) }\end{array}$} & $\begin{array}{l}\text { Formalization of Reusability in } \\
\text { Systems Design }\end{array}$ & $0.38^{*}$ & 0.10 \\
\cline { 2 - 4 } & Formalization of Design Methods & $0.60^{*}$ & 0.13 \\
\cline { 2 - 4 } & Fact Based Management & $0.96^{*}$ & $0.74^{*}$ \\
\cline { 2 - 4 } & Process Control & $0.78^{*}$ & $0.25^{*}$ \\
\hline \multirow{3}{*}{$\begin{array}{l}\text { Stakeholder Participation } \\
\text { (formative) }\end{array}$} & Programmer/ Analysts Empowerment & $0.83^{*}$ & $0.51^{*}$ \\
\cline { 2 - 4 } & User Participation & $0.79^{*}$ & $0.46^{*}$ \\
\cline { 2 - 4 } & Vendor Participation & $0.62^{*}$ & $0.35^{+}$ \\
\hline \multirow{2}{*}{$\begin{array}{l}\text { Quality Performance } \\
\text { (formative) }\end{array}$} & Product Quality & $0.97^{*}$ & $0.83^{*}$ \\
\cline { 2 - 4 } & Process Efficiency & $0.68^{*}$ & $0.30^{+}$ \\
\hline
\end{tabular}

${ }^{*} p \leq .01 ;{ }^{+} p \leq .05$

Significance tests and estimates of confidence intervals for the path coefficients are not directly provided by the PLS method. In order to estimate the significance of path coefficients, a bootstraping technique was used to generate 200 samples. The path coefficients were re-estimated using each of these samples of observations. This vector of parameter estimates was used to compute parameter means, standard errors, path coefficient significance, indicator loadings, and indicator weights. This approach is consistent with recommended practices for estimating significance of path coefficients and indicator loadings (Löhmoller 1984) and has been used in prior IS studies (Chin and Gopal 1995; Compeau and Higgins 1995; Howell and Higgins 1990).

Table 4 shows the weights and loadings for the formative and reflective indicators in the model. The weights indicate the relative importance of the indicators in defining the formative constructs. For formative indicators, which have a regression-like relationship with the latent construct, only the weights (and not the loadings) need to be considered in assessing the measurement model (Chin 1998a). While no minimum threshold values for indicator weights have been established, the statistical significance of the weights can be used to determine the relative importance of the indicators in forming a latent variable. It is seen from Table 4 that all except two indicator weights are statistically significant. Specifically, weights for formalization of reusability $(0.10 ; t=$ $0.244)$ and formalization of design methods $(0.13$; $t=1.281$ ) are not statistically significant. Since we are dealing with newly developed scales, we chose not to refine the measurement model at this point in the theory development process.

In PLS analysis, the predictive power of the structural model is assessed by the $R^{2}$ values of the endogenous constructs. $R^{2}$ values should be 


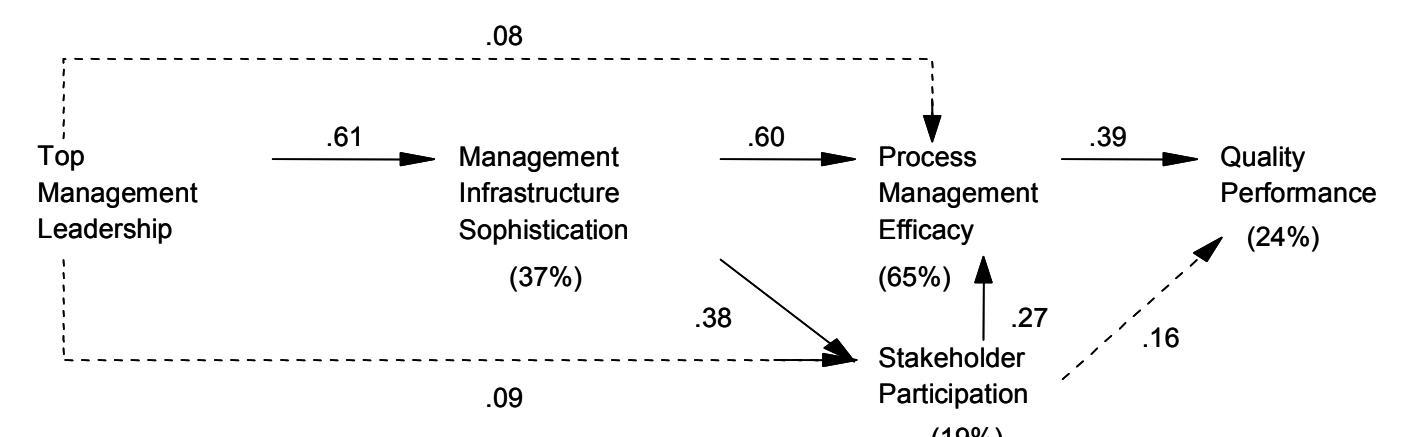

$(19 \%)$

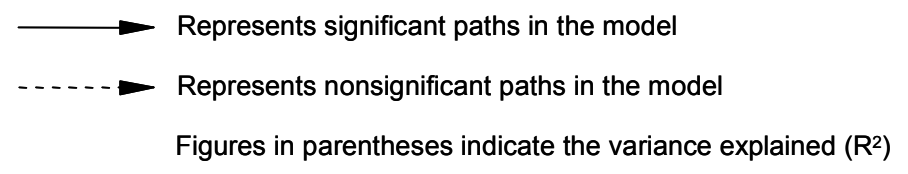

Figure 2. Parameters of the Full Model: Path Coefficients and $\mathbf{R}^{2}$ Values

interpreted in the same manner as those obtained from multiple regression analysis; they indicate the amount of variance in the construct that is explained by the model (Barclay et al. 1995; Chin 1998b). The results (Figure 2 ) indicate that $37 \%$ of the variance in management infrastructure sophistication, $65 \%$ of the variance in process management efficacy, $19 \%$ of the variance in stakeholder participation, and $24 \%$ of the variance in quality performance were explained by the full model.

The direct relationships between top management leadership and process management efficacy and between top management leadership and stakeholder participation as posited in the full model (directed-change) were not supported. An examination of the statistically significant paths (Figure 2) indicates that the causal structure among the antecedents of quality performance is essentially sequential as posited in the nested model. Top management leadership effects the creation of a sophisticated management infrastructure which, in turn, facilitates the design and improvement of the development process and fosters stakeholder participation.

As expected, process management efficacy had a strong positive relationship with quality performance. However, the direct relationship between stakeholder participation and quality performance was not supported. Instead, stakeholder participation was found to have an indirect effect on quality performance by improving the efficacy of the development process.

\section{Decomposed Models}

To develop deeper insights about the quality management phenomenon, we decomposed our nested model and interrelated the individual quality management factors that constituted our constructs. Only the factors that were statistically significant in forming the constructs in the model were included in this phase of our analysis. Accordingly, we excluded two quality management factors (formalization of reusability, formalization of design methods) from our present analysis. Since both product quality and process efficiency were significant in forming the quality performance construct, we examined two decomposed models, one with product quality as the dependent variable, while the other included process efficiency as the dependent variable.

The factors in each of the decomposed models were interrelated with other factors in a manner consistent with the relationships between the 
constructs in the higher-order model. IS management support for quality was the only factor defined as constituting top management leadership and was related to each of the three constituents of management infrastructure. Each factor constituting management infrastructure sophistication was, in turn, linked to each factor constituting process management efficacy and stakeholder participation. Each factor constituting stakeholder participation was linked to the factors forming process management efficacy. The four process management factors were, in turn, linked with product quality in the first decomposed model and with process quality in the second decomposed model. The scale items corresponding with each of the factors were used as their reflective indicators. Both decomposed models had 10 reflective constructs and 42 indicators.

Three unexpected loadings were detected in each of the decomposed models. In both models, the two indicators of vendor participation had negative loadings and one indicator (vendors are pressed to furnish quality data) of the fact based management construct had a low loading $(<.31$ in both models). We dropped the vendor participation factor and the indicator with low loading associated with the fact based management factor and then reassessed both models. The indicator loadings were identical in both models and all of them were now statistically significant. Furthermore, in both models, 33 out of the 39 indicators had loadings greater than .707, and the loadings for the other items were close to this value. In both models, one item under quality policy (item e, .56 see Appendix A), one item under quality orientation of rewards (item c, .63), two items under fact based management (item g, .64 and item h, .67 ), and two items under commitment to skill development (item a, .63 and item d, .64) had loadings that were less than .707. In addition, the loading of one item (item $d, .64$ ) under process efficiency was below .707 .

The path coefficients of the two decomposed models provided support for our higher-order model. A total of 16 of the 21 paths was statistically significant in the product quality model (Figure 3), while one additional path was statistically insignificant in the process efficiency model (Figure 4). The decomposed models explained
$22.6 \%$ of the variance in product quality and $11.2 \%$ of the variance in process efficiency. We interpret the results of the higher-level model and the two decomposed models in the next section.

\section{Discussion}

Previous IS research has examined a myriad of technology-based approaches and some organizational and sociopsychological issues that can impact systems development outcomes, including quality. Our objective was to add to our theoretical and practical understanding of how IS organizations can develop capabilities to manage software quality. We approached this objective by drawing upon theories in macro-organizational design, organizational change, and TQM, and developing and testing a theory for software quality management. We identified key antecedents of quality performance and theoretically interrelated them to propose a model of software quality management. IS leadership was found to be positively associated with management infrastructure sophistication which, in turn, was positively associated with both process management efficacy and stakeholder participation. Process management efficacy was positively associated with quality performance.

An important finding emerging from our results is that discrete quality-oriented practices are unlikely to impact quality performance substantially. Instead, their interactions create an organizational system that plays a pivotal role in the determination of observed levels of quality performance. This finding is consistent with Deming's (1986) assertion that system factors account for far greater variance in work performance than individual or technology factors. Our results emphasize that a coherent, integrated strategy encompassing adoption of all identified factors is required, as opposed to the implementation of one tool or management practice. There are critical, and often overlooked, links between leadership, management infrastructure practices, and process level activities. Each one of these elements is important in its own right; what is more important is the synergy to be realized by focusing on the relationship between these elements. Leadership 

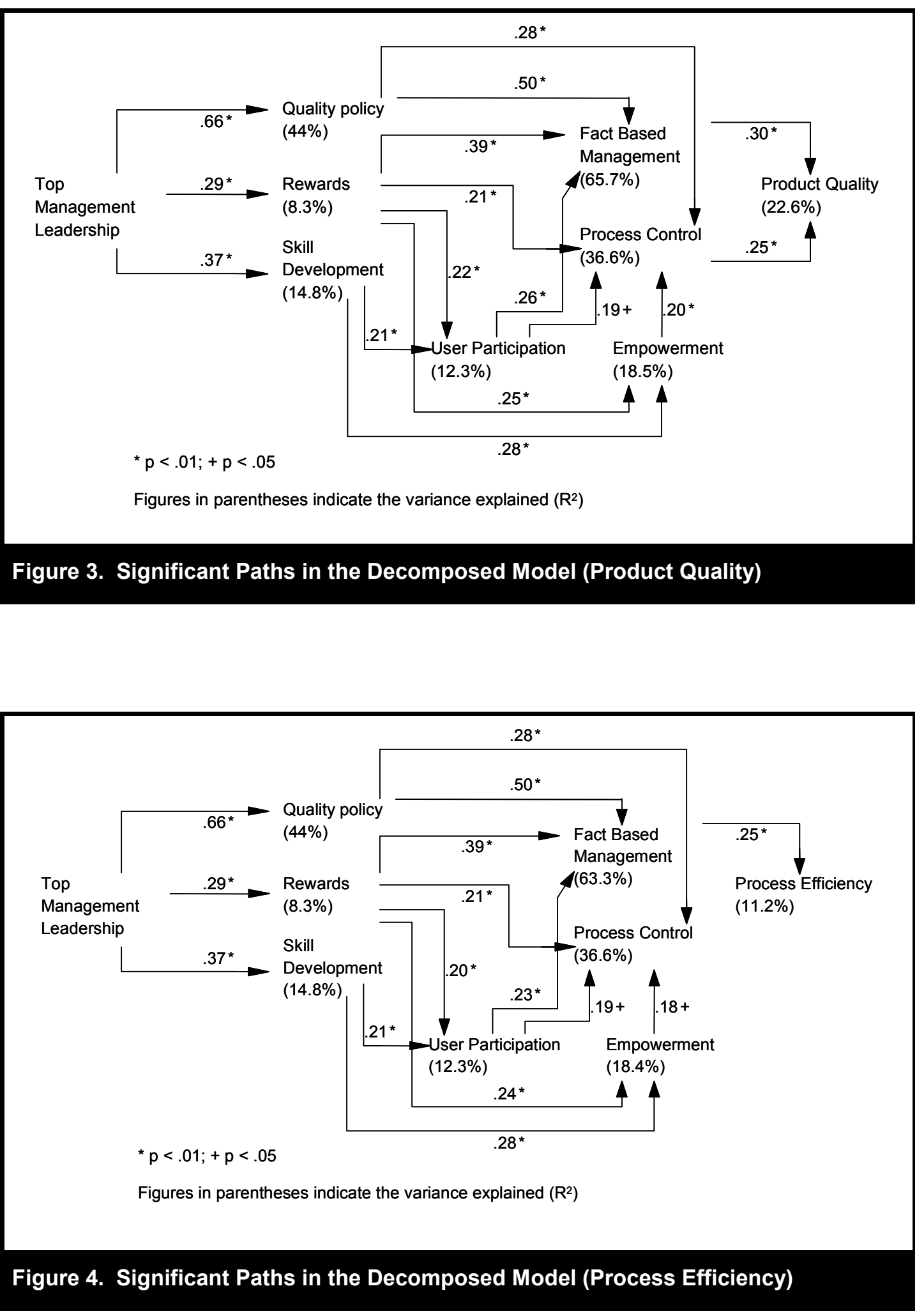
must provide a clear, unambiguous commitment to quality and establish a set of management infrastructure practices that nurture and challenge system development stakeholders to learn about the very processes they interact with on an ongoing basis. By designing an organizational system for the promotion, integration, and coordination of such learning, an IS organization establishes a management framework that is oriented toward ongoing improvement of its products and services and the processes that deliver them.

We posited and observed a significant positive relationship between top management leadership and management infrastructure sophistication. No weaknesses were detected in this relationship, as in both decomposed models IS management support for quality was found to significantly impact each of the three management infrastructure factors. While senior IS executives play a crucial role in creating systemic capabilities, our results suggest that they must tread a careful line between providing direction and facilitating autonomous change at the operational level. The empowered-change perspective suggests that while top management leadership effects the creation of appropriate infrastructure capabilities, it does not have a direct effect on either the operational processes or the associated behavioral processes. Directives from senior IS managers to effect design changes to the development process are unlikely to be beneficial. Instead, senior IS management should focus on creating an environment supportive of learning and improvement in which stakeholders are motivated to initiate process level changes. In high performance organizations, employees do their jobs well because they are committed to a common purpose, not out of compliance to directives from senior management. As a result, users and IS personnel must be given the latitude to take appropriate actions to achieve performance goals. This increased decentralization within system parameters is an important element of a systems approach to software quality improvement.

While software process improvement has received a great deal of attention in the IS literature, many software process improvement frameworks, including the CMM, do not pay adequate attention to the organizational factors that enable or constrain process improvements. The early stages of the CMM focus on process improvement activities and project-related issues, while organizational infrastructure factors are emphasized in the later stages. In contrast, we have argued that improvements to the development process and desired behaviors among stakeholders can be enabled by a carefully conceived management infrastructure. Our empirical results support a strong positive effect of management infrastructure sophistication on process management efficacy and stakeholder participation.

Results of our decomposed model (Figures 3 and 4) analysis reveal additional insights about the impact of management infrastructure elements on process management efficacy and stakeholder participation. Quality orientation of reward schemes positively impacts both the rational design of the systems development work process and the behavioral process of stakeholders. On the other hand, quality policies and goals have a strong effect on the rational design of the development process, but do not significantly impact the behavioral process of stakeholder participation. Similarly, commitment to skill development has a positive effect on both stakeholder participation variables, but does not significantly affect either of the process management efficacy factors we considered in the decomposed models. Our results indicate that the impact of the management infrastructure factors on the rational design of work processes differs from its impact on behavioral factors. Interestingly, while policies have an effect on rational design of work processes, they may not be an effective mechanism to foster behavioral changes. Instead, important behavioral processes, such as stakeholder participation, need to be promoted by design of motivators and appropriate infusion of requisite skills.

How do behavioral processes of key stakeholders' impact the management of systems development? The IS literature provides arguments for managing the behavior of stakeholders during development projects and empirical support for the impact of user participation on development project outcomes. We suggested shifting the focus from the relationship between behavioral processes and development project outcomes to behavioral 
processes and process improvement. Our definition of stakeholder participation included user participation, programmer/analyst empowerment, and vendor participation. Our results provide evidence of a positive relationship between stakeholder participation and process management efficacy. This provides empirical support for our thesis that selected behavioral processes, such as participation, need to be promoted not primarily to obtain superior products in a given development project, but also to promote the ongoing enhancement of development process capability.

Our decomposed model analysis suggests that vendor participation, as defined and measured here, is not a critical part of the nomological network of constructs we used to explain software quality management. However, vendors possess significant technical knowledge about new products and methods that can impact the design of development processes. We recommend that future research further develop the vendor participation factor with a focus on lowering technical knowledge barriers associated with new development tools and methods and the integration of technical knowledge embodied in these tools with the systems of organizations adopting these tools.

Does an organizational system as conceptualized here lead to tangible improvements in systems development performance? Our results suggest that IS management leadership, the management infrastructure of the IS unit, the capability of the development process, and participative behavior of stakeholders interact in a characteristic manner to have a positive impact on systems development performance. The decomposed models provided further support wherein strong positive effects were observed between fact-based management and product quality and between process control and product quality. A positive effect was detected between fact-based management and process efficiency, but no significant relationship was detected between process control and process efficiency (but the path coefficient was a positive and modest .119). Thus, control-oriented activities do not appear to lead to a significant reduction or increase in resource requirements for development, but rather promote a substantially higher quality of developed products.

\section{Implications for IS Theory and Future Research}

Our study contributes to IS theory by integrating concepts and research from organization design and quality management with those in the information systems area. Quality management, IS management, and systems development literatures were integrated to identify critical factors of quality management and quality performance. Using theories of macro-organizational design and organizational change, these factors were synthesized into higher level constructs that together define an organizational system. Interrelationships between these constructs were developed and a theory for software quality management was proposed and tested.

This study is perhaps the first one to go beyond anecdotes and develop theory in software quality management. We recognize that for any theory to be faithful to everyday realities it must be tested with data from diverse sources. The quality management factors and the higher level constructs developed in this study will permit future researchers to use common definitions and assumptions to study the relationships between quality management and quality performance. Researchers are encouraged to question the conceptual and operational definition of these factors and constructs. Researchers are also encouraged to refine the measurement scales developed here, especially the ones that had relatively weak item loadings (Appendix B), such as the scales for commitment to skill development and process efficiency.

Our analysis revealed that some of the identified factors were more significant in forming the higher-order constructs in our model than others. For example, formalization of reusability and formalization of analysis and design methods did not significantly affect process management efficacy. Similarly, vendor participation did not significantly affect stakeholder participation. These results suggest that further refinement of the dimensionalities of these higher-order constructs might be required. For example, process management efficacy can be conceptualized into two dimensions: process design (which includes 
formalization of reusability and design methods) and process improvement (which includes factbased management and process control). Similarly, participation of internal stakeholders (users and programmer/analysts) could be differentiated from participation of external stakeholders (vendors). Such ongoing refinement of the theoretical model presented here is required to enhance our understanding of the antecedents of quality performance and their relationships.

The study opens up other avenues for future research, a few of which are discussed here. Lederer and Mendelow (1990) found that IS management processes are influenced by the contingencies faced by IS units. The concept of equifinality in general systems theory suggests that organizations faced with different contingencies could pursue different paths to attain similar goals. If so, are there contingencies under which the antecedents of quality performance and their proposed causal order could be different? What is the nature of these contingencies and how do they influence the quality management practices? Should organic and mechanistic organiations pursue different paths to improve systems development performance? As part of a broader theory, future studies should identify appropriate contingencies and examine their impact on the software quality management practices presented in our study.

Research in software quality has focused largely on the engineering aspects of software quality assurance and associated tools, methodologies, and testing methods. Such approaches are insufficient to deliver high quality software in time and in a cost-effective manner. This study focused on the socio-behavioral and organizational aspects of software quality management. However, sociobehavioral factors may not ensure the development of technically sound systems. Thus, it is necessary to integrate the technical and sociobehavioral perspectives to develop a more comprehensive understanding of the determinants of quality performance. The present model can be extended to include technical and engineering aspects of software quality management. Sociotechnical systems theory (STS) (Pasmore 1988; Trist and Bamforth 1951), with its explicit focus on the interplay between social and technical aspects of work design, offers a rich theoretical base for such an undertaking. It should be pointed out that a significant body of research exists that has applied STS to systems development (Bostrom and Heinen 1977a, 1977b; Mumford 1983, 1996; Mumford and Weir 1979). However, this stream of research has focused on the design of the larger work system and not specifically on software quality management. We believe that extending the STS perspective to software quality management offers promising research opportunities.

Process-based approaches (such as TQM and CMM) generally recognize that moving from a craft approach, where performance is largely a function of individual skills, to a factory approach, where the process plays a dominant role, is necessary to improve software development performance (Cusumano 1991; Swanson et al. 1991). IS developers could perceive processbased approaches as deskilling their job and increasing managerial control over systems development tasks. Such a change is likely to be resisted by developers and could be a cause for failure of these approaches. STS offers the potential to offset these negative consequences through appropriate job design that allows developers to exercise control over their work and work environment. The empowered change model provides preliminary ideas of how the control systems of process-based approaches can be integrated with participative approaches. We suggested enhancing the influence of developers from striving to reduce process variations to setting more effective standards for achieving desirable outcomes and to altering work processes by observing, interpreting, and reacting to environment change. Clearly, further research that builds on these ideas is required to better understand how the process-based approaches and STS perspectives could be integrated in the context of software quality management.

\section{Implications for IS Practice}

Traditionally "discrete solutions" to the software quality problem have been sought, solutions 
based on one or more of the following aspects: development infrastructure, process improvement, participative design, or project management practices. Our results stress the importance of a systemic approach of developing infrastructure capabilities to enable implementation of qualityoriented processual factors. This approach elevates the management of systems development to levels above the programmer/analyst or project. Treating software quality improvement as a project level issue is unlikely to be effective since organizational impediments to quality improvement, such as a dysfunctional reward system, cannot be effectively dealt with within individual systems development projects. Thus, IS units need to frame quality improvement as an organizational change program and direct attention at managing the transition to a quality-oriented organization.

What is the role of top managers in transitioning to a quality-oriented organizational system? IS managers have to provide the impetus for quality improvement by their active involvement in quality initiatives and through visible signaling that quality is an important priority for the IS organization. Such priority setting is critical to ensure that quality is not ignored under schedule and budgetary pressures, as has been found to happen (Abdel-Hamid 1988). IS managers have to develop a "constancy of purpose" (Deming 1986) for their organization and ensure that short-term pressures faced by the IS unit do not send ambiguous signals about long-term quality objectives. However, they should not consider it their direct responsibility to design the specifics of the development process and its associated management practices. They need to delegate authority and responsibility so that such design decisions emerge from those closest to the development process, namely users, IS personnel and vendors. Such decentralization of decision making is important to create an empowered work setting for IS development where stakeholders are motivated to pool their knowledge resources to improve software quality.

Past studies have reported that administrative practices in IS units are a major impediment to the adoption of software process innovations (Karimi 1990; Leonard-Barton 1987; Ravichandran 1999). Our findings reinforce this notion and highlight that software process improvement involves substantial social change and cannot be accomplished without appropriate administrative changes. Specifically, reward systems should be examined to assess if they constrain stakeholders from sharing insights with each other or inhibit IS developers from translating their experiences into design opportunities for the development process and its management. IS managers should also examine the skill sets of users and IS personnel and allocate resources to develop problem solving, critical thinking, and communication capabilities. These capabilities are necessary for effective participative behavior, wherein both the domain and intent of participation transcends the conduct of individual projects and encompasses process improvement.

There are major implications for the roles of stakeholders, as their responsibility sets are expanded to encompass the design and improvement of the development process. Developers and project managers should actively collaborate with users and vendors to tap into their experiences and insights about improving the development process. Users and developers need to collectively design a system for the acquisition and analysis of process improvement opportunities. They should also examine the processes used in their organization to interpret the applicability of emerging technologies and methodologies. However, the enhanced user and vendor influence over the development process design may not be easily accepted by IS personnel. IS managers have to guard against protectionist behaviors by IS personnel, as well as opportunistic behavior by vendors to tailor the development process to meet their respective goals. They also need to manage against possible disenfranchisement of IS personnel because of increased user influence over systems development tasks.

\section{Limitations of the Study}

While the theory developed here suggests a causal sequence to the relationship among the constructs, imputations of causality should be made with caution. Our data is cross-sectional and not longitudinal in nature. Thus, we cannot say with certainty that IS units included in our 
sample proceeded in the sequence suggested here to develop an organizational system for quality. However, our sample includes IS units that have been implementing the identified practices for varying lengths of time ranging from less than an year to over five years. This acts to increase our confidence in the general applicability of our results throughout the course of designing an organization system for quality.

We used a key informant method for data collection. Both quality management and quality performance data were collected from senior IS managers. It is possible that the self-reported quality performance measures could be biased. However, these measures represent the perceptions of IS executives who, most likely, are responsible for championing quality issues and sanctioning resources for quality improvement initiatives. Their perceptions of product quality and process efficiency will, therefore, be an important factor that influences TQM adoption and implementation. Nevertheless, we suggest that future researchers consider two alternatives in assessing quality performance. First, objective quality measures could be used to complement the perceived measures used here. Objective measures typically assess the quality of individual systems. These measures will have to be aggregated into an overall index of quality performance for the IS unit. Such aggregation would be necessary if the unit of analysis, as in our study, is the IS organization and not individual systems or development projects. Therefore, careful thought has to be given to how system level quality measures can be aggregated to develop an objective quality performance measure for the entire IS organization. Second, quality performance could be measured by surveying multiple respondents, such as end users, programmer/analysts, and IS managers. This method has the advantage of using multiple respondents and can yield a richer data set. However, if a survey method is used, it is likely that the sample size would be low since only firms with matched responses from users and IS managers could be included in the analysis. A different research design, such as an in-depth field study in pre-selected organizations, can be used to investigate how the antecedents of quality performance evolve over time.

\section{Conclusion}

We began this inquiry with the idea that there are systemic drivers of quality. A major focus of the study was to identify the components of an organizational system for quality and develop the theoretical relationships between them. The results suggest that quality performance stems from a discrete set of antecedent conditions that are causally connected. Further, they suggest that these conditions develop in a characteristic sequence and that all identified conditions need to be developed to attain significant improvements in quality performance.

The study represents a significant effort at integrating diverse, yet complementary literature streams to develop theory in an important area of IS research, namely software quality management. The results are interesting and highlight that IS research in this area can be enriched by quality management concepts and principles. Further, the study identifies critical organizational levers that IS managers can manipulate in their efforts to improve software quality performance.

\section{Acknowledgements}

The authors thank the Senior Editor, Robert Zmud, the Associate Editor, and the anonymous reviewers for their helpful comments, which significantly enhanced the quality of the manuscript. This research was partially supported by the Pontikes Center for Management of Information, Southern Illinois University at Carbondale.

\section{References}

Abdel-Hamid, T. "The Economics of Software Quality Assurance: A Simulation-Based Case Study," MIS Quarterly (12:3), September 1988, pp. 394-411.

Adler, P. S. "CAD/CAM: Managerial Challenges and Research Issues," IEEE Transactions on Engineering Management (36:3), 1989, pp. 202215.

Ahire, S. L., Golhar, D. Y., and Waller, A. M. "Development and Validation of TQM Imple- 
mentation Constructs," Decision Sciences (27:1), 1996, pp. $23-56$.

Ahituv, N., and Zelek, M. "Instant Quality Control of Large Batch Processing Jobs," MIS Quarterly (11:3), 1987, pp. 313-323.

Anderson, J. C., and Gerbing, D. W. "Structural Equation Modeling in Practice: A Review and Recommended Two-step Approach," Psychological Bulletin (103:3), 1988, pp. 411-423.

Anderson, J. C., Rungtusanthanam, M., and Schroeder, R. "A Theory of Quality Management Underlying the Deming Management Method," The Academy of Management Review (19:3), 1994, pp. 473-509.

Anderson, J. C., Rungtusanthanam, M., Schroeder, R., and Devaraj, S. "A Path Analytic Model of a Theory of Quality Management Underlying the Deming Management Method: Preliminary Empirical Findings," Decision Sciences (26:5), 1995, pp. 637-658.

Anthes, G. H. "Quality? What's That?" Computerworld, October 13, 1997, pp. 75-76.

Apte, U., Sankar, S. C., Takur, M., and Turner, E. J. "Reusability-Based Strategy for Development of Information Systems: Implementation Experience of a Bank," MIS Quarterly (14:4), December 1990, pp. 421-433.

Bailey, J. E., and Pearson, S. W. "Development of a Tool for Measuring and Analyzing Computer User Satisfaction," Management Science (29:5), 1983, pp. 519-529.

Baldrige Award. Malcolm Baldrige National Quality Award, National Institute of Standards and Technology, Washington, DC, 1992.

Banker, R. D., and Kauffman, R. J. "Reuse and Productivity in Integrated Computer-Aided Software Engineering: An Empirical Study," MIS Quarterly (15:3), September 1991, pp. 375-401.

Barclay, D., Higgins, C., and Thompson, R. "The Partial Least Squares Approach to Causal Modeling: Personal Computer Adoption and Use as an Illustration," Technology Studies (2:2), 1995, pp. 285-309.

Barki, H., and Hartwick, J. "Rethinking the Concept of User Involvement," MIS Quarterly (13:1), March 1989, pp. 52-63.

Barnard, C. The Functions of the Executive, Harvard University Press, Cambridge MA, 1938.

Bass, B. M. Leadership and Performance Beyond Expectations, Free Press, New York, 1985.
Bendure C. O. "A Case Study on CASE: Its Evolution and Use at HHMI," Journal of Information Systems Management (8:4), 1991, pp. 50-56.

Bjerknes, G., and Bratteteig, T. "User Participation and Democracy: A Discussion of Scandinavian Research on System Development," Scandinavian Journal of Information Systems (7:1), 1995.

Blackburn, R., and Rosen, B. "Total Quality and Human Resources Management: Lessons Learned from Baldrige Award Winning Companies," Academy of Management Executive (7:3), 1993, pp. 49-66.

Bollen, K. A. Structural Equations with Latent Variables, John Wiley, New York, 1989.

Bostrom, R. P., and Heinen, J. S. "MIS Problems and Failures: A Sociotechnical Perspective, Part I: The Causes," MIS Quarterly (1:3), 1977a, pp. 17-32.

Bostrom, R. P., and Heinen, J. S. "MIS Problems and Failures: A Sociotechnical Perspective, Part I: The Application of Sociotechnical Theory," MIS Quarterly (1:4), 1977b, pp. 11-28.

Bødker, S., Ehn, P., Kammersgaard, J., Kyng, M., and Sundblad, Y. "A UTOPIAN Experience: On Design of Powerful Computer-Based Tools for Skilled Graphic Workers," in Computers and Democracy: A Scandinavian Challenge, G. Bjerknes, P. Ehn, and M. Kyng (eds.), Avebury, Aldershot, UK, 1987, pp. 251-278.

Camuffo, M., Maiocchi, M., and Morselli, M. "Automatic Software Test Generation," Information and Software Technology (32:2), 1990, pp. 337-346.

Card, D. "Understanding Process Improvement," IEEE Software (8:4), July 1991, pp. 102-103.

Carlson, J., Ehn, P., Erlander, B., Perby, M., and Sandberg, A. "Planning and Control from the Perspective of Labor: A Short Presentation of the DEMOS Project," Accounting, Organizations, and Society (3:1), 1978, pp. 3-4.

Checkland, P., and Scholes, J. Soft Systems Methodology in Action, John Wiley and Sons, Chichester, UK, 1990.

Chin, W. W. "Issues and Opinion on Structural Equation Modeling," MIS Quarterly (22:1), 1998a, pp. vii - xvi.

Chin, W. W "The Partial Least Squares Approach for Structural Equation Modeling," in Modern 
Methods for Business Research, G. A. Marcoulides (ed.), Lawrence Erlbaum Associates, Hillsdale, NJ, 1998b, pp 295-336.

Chin, W. W., and Gopal, A. "Adoption Intention in GSS: Relative Importance of Beliefs," Data Base Advances (26:2/3), 1995, pp. 42-63.

Cohen, P., Cohen, J. T., Marchi, M., and Velez, C. N. "Problems in the Measurement of Latent Variables in Structural Equation Causal Models," Applied Psychological Measurement (14), 1990, pp. 183-196.

Cole, R. E. "The Japanese Lesson in Quality," Technology Review (83), 1981, pp. 29-40.

Compeau, D. R., and Higgins, C. A. "Computer Self-Efficacy: Development of a Measure and an Initial Test," MIS Quarterly (19:2), 1995, pp. 189-211.

Conger, J. A., and Kanungo, R. N. "The Empowerment Process: Integrating Theory and Practice," Academy of Management Review (13:3), 1987, pp. 471-482.

Crosby, P. Quality is Free, Mentor Publishing, New York, 1979.

Cusumano, M. A. Japan's Software Factories, Oxford University Press, Oxford, UK, 1991.

Dean J. W., and Bowen, D. E. "Management Theory and Total Quality: Improving Research and Practice Through Theory Development," The Academy of Management Review (19:3), 1994, pp. 387-418.

Deming, E. Out of the Crisis, MIT Center for Advanced Engineering, Cambridge, MA, 1986.

Directory of Top Computer Executives. Applied Research Inc., Phoenix, Arizona, 1994.

Diaz, M., and Sligo, J. "How Software Process Improvement Helped Motorola," IEEE Software (14:5), 1997, pp. 75-81.

Drucker, P. F. "The Emerging Theory of Manufacturing," Harvard Business Review (68:3), May-June 1990, pp. 94-102.

DUE Project Group. "Project DUE: Democracy, Development, and EDP," in Computers Dividing Man and Work Swedish Center for Working Life: Demos Project Report No. 13, A. Sandberg (ed.), Utbildningsproduktion, Malmö, Sweden, 1979, pp. 122-130.

Ehn, P., and Kyng, M. "A Tool Perspective on Design of Interactive Computer Support for Skilled Workers," in Report of the Seventh Scandinavian Research Seminar on Sys- temeering Helsinki School of Economics, Studies B-74, J. Sääksjärvi (ed.), Helsinki, 1984, pp. 211-242.

Ehn, P., and Sandberg, A. "Local Union Influence on Technology and Work Organization: Some Results From the DEMOS Project," in Systems Design For, With and By the Users, U. Briefs, C. Ciborra, and L. Schneider (eds.) North-Holland, Amsterdam, 1993, pp. 427-437.

Feigenbaum, A. V. Total Quality Control ( $4^{\text {th }}$ ed.), McGraw-Hill, New York, 1991.

Fenwick, A. C. "Five Easy Lessons," Quality Progress (24:12), December 1991, pp. 63-66.

Flynn, B., Schroeder, R. G., and Sakakibara, S. "A Framework for Quality Management Research and an Associated Measurement Instrument," Journal of Operations Management (11:4), 1994, pp. 339-366.

Flynn, B., Schroeder, R. G., and Sakakibara, S. "The Impact of Quality Management Practices on Performance and Competitive Advantage," Decision Sciences (26:5), 1995, pp. 659-692

Fox, C., and Flakes, W. "The Quality Approach: Is It Delivering," Communications of the ACM (40:6), 1997, pp. 25-29.

Franz, C. R., and Robey, D. "Organizational Context, User Involvement and the Usefulness of Information Systems," Decision Sciences (17), 1986, pp. 329-355.

Galletta, F. G., and Lederer, A. L. "Some Cautions on the Measurement of User Information Satisfaction," Decision Sciences (20:3), 1989, pp. 419-438.

Garvin, D. A. "Competing on the Eight Dimensions of Quality," Harvard Business Review (65:6), November-December 1987, pp. 101-109.

Garvin, D. A. "The Process of Organization and Management," Sloan Management Review (39:4), Summer 1998, pp. 33-50.

Grant, R. M., Shani, R., and Krishnan, R. "TQM's Challenge to Management Theory and Practice," Sloan Management Review, Winter 1994, pp. 25-35.

Grover, V. "A Tutorial on Survey Research: From Constructs to Theory," http://theweb.badm. sc.edu/grover/survey/MIS-SUVY.html, 1997.

Haley, T. J. "Raytheon's Experience in Software Process Improvement," IEEE Software (13:2), 1996, pp. 33-41.

Hamilton, S., and Chervany, N. L. "Evaluating Information Systems Effectiveness: Comparing 
Evaluation Approaches," MIS Quarterly (5:1), September 1981, pp. 55-69.

Hartwick, J., and Barki, H. "Explaining the Role of User Participation in Information Systems Use," Management Science (40:4), 1994, pp. 440465.

Hirschheim, R., and Klein, H. "Realizing Emancipatory Principles in Information Systems Development: The Case for ETHICS," MIS Quarterly (18:1), March 1994, pp. 83-109.

Hollenbach, C., Young, R., Pflugrad, A., and Smith, D. "Combining Quality and Software Process Improvement," Communications of the ACM (40:6), 1997, pp. 41-45.

House, R. J. "A 1976 Theory of Charismatic Leadership," in Leadership: The Cutting Edge, J. G. Hunt, and L. L Larson (eds.), Southern Illinois University Press, Carbondale, IL, 1977, pp. 189-207.

Howell, J. M., and Higgins, C. A. "Champions of Technological Innovation," Administrative Science Quarterly (35:2), 1990, pp. 317-341.

Ivari, J., and Koskela, E. "The PIOCO Model for IS Design," MIS Quarterly (11:3), September 1987, pp. 401-419.

Ives, B., Olson, M. H., and Baroudi, J. J. "The Measurement of User Information Satisfaction," Communications of the ACM (26:10), 1983, pp. 785-793.

Juran, J. M. Quality Control Handbook, McGraw Hill, New York, 1986.

Kane, E. J. "Implementing TQM at Dun \& Bradstreet Software," National Productivity Review (11:3), Summer 1992, pp. 405-416.

Karimi, J. "An Asset-Based Systems Development Approach to Software Reusability," MIS Quarterly (14:2), June 1990, pp. 178-198.

Klein, H. K., and Hirschheim, R. "The Application of Neohumanist Principles," in Information Systems Development, in Human, Organizational and Social Dimensions of Information Systems Development, D. Avison, J. Kendall, and J. I. DeGross (eds.), North-Holland, Amsterdam, 1993, pp. 262-280.

Kyng, M., and Mathiassen, L. "Systems Development and Trade Union Activities," in Information Society: For Richer, For Poorer, N. BjørnAndersen, M. Earl, J. Holst, and E. Mumford (eds.), North-Holland, Amsterdam, 1982.

Lanzara, G., and Mathiassen, L. "Mapping Situations Within a Systems Development Project,"
Information and Management (8:1), 1985, pp. 320.

Lederer, A. L., and Mendelow, A. "The Impact of the Environment on the Management of Information Systems," Information Systems Research (1:2), 1990, pp. 205-222.

Leifer, R., Lee, S., and Durgee, J. "Deep Structures: Real Information Requirements Determination," Information and Management (27:5), 1994, pp. 275-285.

Leonard-Barton, D. "Implementing Structured Software Methodologies: A Case of Innovation in Process Technology," Interfaces (17:3), 1987, pp. 6-17.

Löhmoeller, J. B. LVPS 1.6 Program Manual: Latent Variable Path Analysis with Partial Least Squares Estimation, Universitaet zu Koehn, Zentralarchiv fuer Empirische Sozialforschung, Munich, 1984.

Mathiassen, L., and Bøgh-Andersen, P. "Systems Development and Use: A Science of the Truth or a Theory of Lies," in Computers and Democracy, G. Bjerkenes, P. Ehn, and M. Kyng (eds.), Avebury, Aldershot, UK, 1987, pp. 395417.

Mantei, M. M., and Teory, T. J. "Incorporating Behavioral Techniques into the Systems Development Life Cycle," MIS Quarterly (13:3), September 1989, pp. 257-275.

Melcher, A. J. Structure and Process of Organizations, Prentice-Hall, Englewood Cliffs, NJ, 1976.

Mumford, E. Designing Human Systems: The ETHICS Method, Manchester Business School, Manchester, UK, 1983.

Mumford, E. Systems Design: Ethical Tools for Ethical Change, Macmillan, London, 1996.

Mumford, E., and Henshall, D. A Participative Approach to Computer Systems Design, Associated Business Press, London, 1979.

Mumford, E., and Weir, M. Computer Systems in Work Design-The ETHICS Method, John Wiley and Sons, London, 1979.

Munson, J., and Khoshgoftaar, T. "The Detection of Fault Prone Programs," IEEE Transactions on Software Engineering (18:5), 1992, pp. 423433.

Nunnally, J. C. Psychometric Theory, McGraw Hill, New York, 1988.

Okumoto, K. A. "Statistical Method for Software Quality Control," IEEE Transactions on Software Engineering (11:12), 1985, pp. 1424-1430. 
Pasmore, W. A. Designing Effective Organizations: The Sociotechnical Systems Perspective, John Wiley and Sons, New York, 1988.

Paulk, M. C., Weber, C. V., Curtis, B., and Chrissis, M. B. The Capability Maturity Model: Guidelines for Improving the Software Process, Software Engineering Institute, Carnegie Melon University, Pittsburgh, 1995.

Pfleeger, S. L "Realities and Rewards of Software Process Improvement," IEEE Software (13:6), November 1996, pp. 99-101.

Pinsonneault, A., and Kraemer, K. L. "Survey Research Methodology in Management Information Systems: An Assessment," Journal of Management Information Systems (10:2), 1993, pp. 75-105.

Rai, A., Song, H., and Troutt, M. "Software Quality Assurance: An Analytical Survey and Research Prioritization," The Journal of Systems and Software (40:1), 1998, pp. 67-84.

Ravichandran, T. "Software Reusability as Synchronous Innovation: A Test of Four Theoretical Models," European Journal of Information Systems (8:3), 1999, pp 183-199.

Ravichandran, T., and Rai, A. "Total Quality Management in Information Systems Development: Key Constructs and Relationships," Journal of Management Information Systems (16:3), Winter 1999, pp. 124-155.

Robey, D. Designing Organizations (2 $\left.{ }^{\text {nd }} e d.\right)$, Irwin, Homewood, IL, 1986.

Rockart, .J. F., and Hofman, J. D. "Systems Delivery: Evolving New Strategies," Sloan Management Review (33:4), Summer 1992, p 57-64.

Rowe, J. M., and Neal, R. D. "TQM in Systems Development: A Paradigm Without a Sound Foundation," Journal of Systems Management (44:5), May 1993, pp. 12-16.

Rummens, N., and Sucher, R. "CASE: Competitive Edge," Systems International (UK) (17:3), March 1989, pp. 31-34.

Saiedian, H., and Kuzara, R. "SEI Capability Maturity Model's Impact on Contractors," IEEE Computer (28:1), January 1995, pp. 16-26.

Saracelli, K. D., and Bandat, K. F. "Process Automation in Software Application Development," IBM Systems Journal (32:3), 1993, pp. 376-396.

Saraph, J. V., Bensen, P. G., and Schroeder, R. G. "An Instrument for Measuring the Critical
Factors of Quality Management," Decision Sciences (20:4), 1989, pp. 810-829.

Schoenberger, R. J. Total Quality Management: Nine Hidden Lessons in Simplicity, Productivity Press, Portland, OR, 1984.

Scholtes, P., and Hacquebord, H. "Beginning the Quality Transformation," Quality Progress, July 1988, pp. 28-33.

Selznick, P. Leadership in Administration, Harper and Row, New York, 1957.

Shingo, S. Zero Quality Control: Source Inspection and Poka-Yoke Systems, Productivity Press, Portland, OR, 1986.

Shores, R. "Improving the Quality of Management Systems," Quality Progress (25:6), June 1992, pp. 53-57.

Shrednick, H. R., Shut, R. J., and Weiss, M. "Empowerment: Key to IS World-Class Quality," MIS Quarterly (16:4), December 1992, pp. 491505.

Sitkin, S. B., Sutcliffe, K. M., and Schroeder, R. G. "Distinguishing Control from Learning in Total Quality Management: A Contingency Perspective," The Academy of Management Review (19:3), 1994, pp. 537-564.

Spencer, B. "Models of Organization and Total Quality Management: A Comparison and Critical Evaluation," The Academy of Management Review (19:3), 1994, pp. 446-471.

Stylianou, A., Kumar, R., and Khouja, M. A. "A TQM-Based Systems Development Process, DATABASE for Advances in Information Systems (28:3), 1997, pp. 59-71.

Swanson, K., McComb, D., Smith, J., and McCubbery, D. "The Application Software Factory: Applying Total Quality Techniques to System Development," MIS Quarterly (15:4), December 1991, pp. 566-579.

Taguchi, G., and Clausing, D. "Robust Quality," Harvard Business Review (68:1), JanuaryFebruary 1990, pp. 65-75.

Taylor, F. E. The Principles of Scientific Management, Harper and Brothers, New York, 1911.

Tichy, N. M., and Devanna, M. A. The Transformational Leader, Wiley, New York, 1986.

Trist, E., and Bamforth, K. "Some Social and Psychological Consequences of the Longwall Method of Coal-Getting," Human Relations (1), 1951, pp. 3-38.

Venkatraman, N. "Strategic Orientation of Business Enterprises: The Construct, Dimensionality 
and Measurement," Management Science (35:8), 1989, pp. 942-962.

Waldman, D. A. "The Contribution of Total Quality Management to a Theory of Work Performance," The Academy of Management Review (19:3), 1994, pp. 510-536.

Walrad, C., and Moss, E. "Measurement: The Key to Application Development Quality," IBM Systems Journal (32:3), 1993, pp. 445-460.

Werts, C. E., Linn, R. L., and Joreskög, K. G. "Interclass Reliability Estimates: Testing Structure Assumptions," Educational and Psychological Measurement (34:1), 1974, pp. 25-33.

Williamson, M. "Getting a Handle on CASE," CIO (3:7), 1990, pp. 42-51.

Williamson, M. "Quality Pays," Computerworld, August 18, 1997, pp 78-81.

Winter, M. C., Brown, D. H., and Checkland, P. B. "The Role of Soft Systems Methodology in Information Systems Development," European Journal of Information Systems (4), 1995, pp. 130-142.

Yates, W. D., and Shaller, D. A. "Reliability Engineering as Applied to Software," Proceedings of Reliability and Maintainability Symposium, 1990, pp. 425-429.

$\mathrm{Yu}, \mathrm{J}$., and Cooper, H. "A Quantitative Review of Research Design Effects on Response Rates to Questionnaires," Journal of Marketing Research (20:2), 1983, pp. 36-44.

Zultner, R. E. "TQM for Technical Teams," Communications of the $\operatorname{ACM}(36: 10), 1993$, pp. 79-91.

\section{About the Authors}

T. Ravichandran is an assistant professor in the Lally School of Management and Technology at Rensselaer Polytechnic Institute. He received his B.E from the University of Madras, a M.S. in Industrial and Systems Engineering from the National Productivity Council, India, and a Ph.D. in MIS from Southern Illinois University at Carbondale. His present research interests are in the following areas: management of systems delivery, strategic implications of information systems capabilities, diffusion and infusion of information technologies, and Internet economics. His research in some of these areas is being supported by grants from the National Science Foundation. His research has been published in Communications of the ACM, European Journal of Information Systems, Journal of Management Information Systems, and the proceedings of several national and international conferences. Ravi is a member of the Academy of Management, Association of Computing Machinery, Association for Information Systems, Decision Sciences Institute and INFORMS.

Arun Rai is a professor in the Electronic Commerce Institute, Robinson College of Business, Georgia State University. His research interests include the diffusion, infusion, and impacts of information technology, emergent eBusiness models, supply chain management, knowledge management, and management of unstructured processes, such as innovation, product development, and systems development. Arun's research has been published in journals such as Annals of Operations Research, Accounting, Management and Information Technologies, Communications of the ACM, Decision Sciences, Decision Support Systems, European Journal of Information Systems, Information Systems Journal, Journal of Management Information Systems, Omega, and several others. He has served as an associate editor of MIS Quarterly and currently serves as associate editor for Database for Advances in Information Systems, e-Services Journal, and Information Resources Management Journal. Leading corporations, such as A. T. Kearney, Bozell Worldwide, Chrysler, Comdisco, IBM, and Scientific Atlanta, among others, have sponsored his recent research work. 


\section{APPENDIX A}

\section{Outline of the Questionnaire Used for the Study}

All items except those for scale 6 solicit responses on a seven point Likert scale with $1=$ Strongly Disagree, 2 = Disagree, 3 = Disagree Slightly, $4=$ Neutral, $5=$ Agree Somewhat, $6=$ Agree, and $7=$ Strongly Agree. Items for scale 6 (formalization of reusability in systems development) solicit responses on a five point scale with $1=$ None, $2=$ Low, $3=$ Moderate, $4=$ High, and $5=$ Very High. During data analyses the responses for scale 6 were normalized to a seven point scale to maintain uniform scale width for all constructs.

The following items pertain to quality management practices in your information systems department (ISD). For each item, please circle the choice that best indicates current practices in your ISD.

1. IS Management Support for Quality

(a) IS chief executive assumes responsibility for quality performance

(b) IS chief executive is evaluated for quality performance

(c) IS chief executive supports quality improvement processes

2. Quality Policy and Goals
(a) IS management has clear quality objectives
(b) Quality goals within IS are very specific
(c) There is a comprehensive IS quality plan
(d) Quality goals and policy are understood within the department
(e) Significant importance is attached to quality in relation to cost and schedule objectives.

3. Quality Orientation of Reward Schemes

(a) Development cycle time, cost and productivity are used as the basis for rewards for IS personnel

(b) User satisfaction is an important factor in determining rewards for IS personnel

(c) Quality measures like error rate and scrap rate are used as the basis for rewards for IS personnel

(d) Incentives are used to promote reusability

4. Commitment to Skill Development

(a) Regular training in quality management tools and techniques is given to IS personnel

(b) Team building and group dynamics training are given to IS personnel

(c) Business skills training is given to IS personnel

(d) Resources are made available for training IS personnel

5. Formalization of Analysis and Design

(a) Formal techniques such as JAD and prototyping are regularly used for requirement elicitation

(b) Idea generation techniques such as brain storming are used in system design

(c) Formal techniques such as quality function deployment are used to translate user requirements into design

(d) Standard representation schemes such as ER diagrams and DFD are used for design specifications 
6. Formalization of Reusability in Systems Development

(a) Extent to which formal policies to promote development of reusable design/code are implemented

(b) Extent to which formal policies that mandate use of reusable components are implemented

(c) Extent to which reuse of code/design components is monitored

(d) Extent to which formal policies on parameterization of design/code are implemented

7. Fact Based Management

(a) Quality data is collected and reported at frequent intervals

(b) Vendors/consultants are pressed to furnish quality data

(c) Performance levels are benchmarked with those of other firms

(d) Quality problems are analyzed to identify problem causes

(e) Quality data is systematically used in managing systems development

(f) Cost of quality is analyzed

(g) Metrics are recalibrated to reflect changes in the development process

(h) Best practices are systematically institutionalized

8. Process Control

(a) Performance standards have been established for design

(b) Performance standards have been established for programming

(c) Performance standards have been established for testing

(d) Performance standards are used to monitor and control output

(e) Performance standards are revised annually/regularly

9. User Participation

(a) Users actively participate in determining system requirements

(b) Users actively participate in identifying input/output needs

(c) Users actively participate in developing test plans

10. Vendor Participation

(a) Long term partnerships have been established with key vendors/consultants

(b) Vendors/consultant form an integral part of the systems delivery process

11. Programmer/Analyst Empowerment

(a) Team members participate in project planning

(b) Team members participate in decisions regarding resource allocation to projects

(c) Project schedules are determined in consultation with team members

12. Product Quality

(a) Users perceive that the system meets intended functional requirements

(b) The information provided by the systems meets user expectations

(c) Systems meet user expectations with respect to response time, flexibility and ease of use

(d) Users are satisfied with the overall quality of the systems 


\section{Process Efficiency}

(a) Projects usually overrun budgeted costs

(b) Schedule overruns are common in most projects

(c) Backlog of development work is high

(d) Fixing bugs and other types of rework account for a significant proportion of systems development effort.

\section{APPENDIX B}

\section{Summary of Scale Validation ${ }^{5}$}

We used confirmatory factor analysis for scale validation. The scales were factor analyzed using LISREL. This involved specifying a measurement model for each scale defined according to the weighted linear combination of their constituent items and assessing the fit of the specified measurement model to the data. Such a specification subscribes to a causal-indicator model where the observed indicators are reflective of the unobserved theoretical construct. Typically, a causal-indicator model is specified and analyzed for each theoretical construct individually (Ahire et al. 1996; Venkatraman 1989). We followed these guidelines for all constructs with four or more indicators. Constructs with a lesser number of indicators were pooled and analyzed in order to provide adequate degrees of freedom for estimation of model parameters.

Degrees of freedom pertains to the number of bits of information available for estimating the sampling distribution of the data after all model parameters have been estimated. In practical terms, the degrees of freedom are the number of nonredundant covariance in the input matrix minus the number of estimated parameters. Measurement models with three indicator variables are just identified with one degree of freedom and will yield a perfect fit. Models with a lesser number of indicators are underidentified and will always yield incorrect loadings. One approach to overcome both of these problems is to pool the indicators for underidentified and just identified constructs and specify a combined measurement model. In our study, three constructs (IS commitment to quality, empowerment of programmer/analysts, user participation) have three items and one construct (vendor participation) has two items. Items for these four constructs were pooled and analyzed resulting in a model that was overidentified with 38 degrees of freedom.

Following guidelines for scale validation (Anderson and Gerbing 1988; Bollen 1989), a series of analyses were done to assess unidimensionality, reliability, convergent validity, and discriminant validity of both the quality management and quality performance constructs and the criterion related validity of the quality management constructs. These are briefly summarized below.

In confirmatory factor analysis, unidimensionality is tested by specifying a measurement model that defines the relationship between each construct and its constituent items. A good fit of the measurement model indicates that, as hypothesized, all items load significantly on one underlying latent variable and that the scale is unidimensional. The goodness of fit index (GFI) is high for all scales, indicating that the scales are unidimensional.

\footnotetext{
${ }^{5}$ For a more detailed discussion of the scales and their validation, the reader is referred to Ravichandran and Rai (1999).
} 
Scale reliability was assessed using Cronbach's alpha and the Werts et al. (1990) $\rho_{c} \rho_{c}$ represents the ratio of trait variance to the sum of trait and error variance. Scales with $\rho_{c}$ greater than $50 \%$ are considered to be reliable. A minimum Cronbach $s$ alpha of .6 is required for new scales to be considered reliable (Nunnally 1988). The reliability of all the scales are adequate on both criteria.

Convergent validity of the scales was assessed using the Bentler-Bonnet coefficient $(\Delta)$. The BentlerBonnet coefficient represents the ratio of the chi-square value of the specified measurement model to that of a null model which has no hypothesized item loadings on a construct. Scales with $\Delta$ values of .90 or above demonstrate strong convergent validity.

Discriminant validity of the scales was assessed using the following procedure. Confirmatory factor analysis was run on pairs of scales allowing for correlation between them. Next, the procedure was repeated with the correlation between the two scales constrained to be equal to 1 . A significant difference between the constrained model chi-square and that of the unconstrained model indicates that the two scales are distinct (Ahire et al. 1996; Venkatraman 1989). Discriminant validity checks were run for all pairs of the 11 quality management scales and two quality performance scales (a total of 56 tests). The chi-square difference test was found significant $(p<.001)$ for all 56 tests.

Criterion-related validity was assessed by testing the relationships between each of the 11 quality management factors with both product quality and process efficiency. All 22 relationships were in the expected direction; 18 of these relationships were significant providing evidence of the criterion-related validity of the respective quality management constructs. Formalization of reusability in systems development and vendor/consultant participation were not significantly related with product quality and process efficiency. However, the associations were in the expected directions, providing some evidence of the criterion-related validity of these two constructs. 


\begin{tabular}{|c|c|c|c|c|c|}
\hline \multirow[b]{2}{*}{$\begin{array}{c}\text { Construct and Item } \\
\text { Loadings* }^{*}\end{array}$} & \multirow[b]{2}{*}{$\begin{array}{l}\text { Number } \\
\text { of Items }\end{array}$} & \multirow{2}{*}{$\begin{array}{l}\text { Unidimensionality } \\
\text { Goodness of Fit } \\
\text { Index [GFI] }\end{array}$} & \multicolumn{2}{|c|}{ Reliability } & \multirow{2}{*}{$\begin{array}{c}\begin{array}{c}\text { Convergent } \\
\text { Validity }\end{array} \\
\text { Bentler } \\
\text { Bonnet } \Delta\end{array}$} \\
\hline & & & $\begin{array}{c}\text { Cronbach's } \\
\alpha \\
\end{array}$ & $\begin{array}{c}\text { Werts Linn } \\
\text { Jorsekog } \\
\rho_{c}\end{array}$ & \\
\hline $\begin{array}{l}\text { IS management support for } \\
\text { quality }(.90, .74, .60)\end{array}$ & $3^{H}$ & .94 & .79 & .80 & .92 \\
\hline $\begin{array}{l}\text { Quality policy and goals }(.78 \text {, } \\
.89, .77, .77, .41)\end{array}$ & 5 & .96 & .84 & .85 & .95 \\
\hline $\begin{array}{l}\text { Commitment to skill } \\
\text { development }(.34, .65, .92 \text {, } \\
.50)\end{array}$ & 4 & .99 & .70 & .71 & .98 \\
\hline $\begin{array}{l}\text { Quality orientation of reward } \\
\text { schemes }(.57, .77, .45, .62)\end{array}$ & 4 & .97 & .68 & .79 & .91 \\
\hline $\begin{array}{l}\text { Formalization of reusability in } \\
\text { systems development }(.79 \text {, } \\
.95, .79, .56)\end{array}$ & 4 & .99 & .85 & .86 & .99 \\
\hline $\begin{array}{l}\text { Formalization of } \\
\text { analysis/design }(.82, .61 \text {, } \\
.61, .68)\end{array}$ & 4 & .95 & .77 & .78 & .90 \\
\hline $\begin{array}{l}\text { Fact based management } \\
(.78, .48, .53, .75, .91, .69 \\
.68, .56)\end{array}$ & 8 & .93 & .87 & .87 & .92 \\
\hline $\begin{array}{l}\text { Process control }(.95, .97 \text {, } \\
.94, .82, .73)\end{array}$ & 5 & .92 & .95 & .95 & .96 \\
\hline $\begin{array}{l}\text { User participation }(.90, .94 \text {, } \\
.57)\end{array}$ & $3^{H}$ & .94 & .78 & .86 & .92 \\
\hline $\begin{array}{l}\text { Programmer/analyst } \\
\text { empowerment }(.50, .67, .72)\end{array}$ & $3^{H}$ & .94 & .65 & .67 & .92 \\
\hline $\begin{array}{l}\text { Vendor/consultant } \\
\text { participation }(.65, .84)\end{array}$ & $2^{\mathrm{H}}$ & .94 & .71 & .77 & .92 \\
\hline $\begin{array}{l}\text { Product quality }(.85, .83, .67 \text {, } \\
.60)\end{array}$ & 4 & .90 & .82 & .83 & .87 \\
\hline $\begin{array}{l}\text { Process efficiency }(.93, .94 \\
.50, .33)\end{array}$ & 4 & .96 & .78 & .79 & .95 \\
\hline
\end{tabular}

${ }^{\mathrm{H}} \mathrm{A}$ combined model was run for these four constructs.

${ }^{*}$ All item loadings were significant at $p<.001$. 

Ravichandran \& Rai/Quality Management \& Systems Development 